Revista de
GESTÃOAl of Integrated
COSTEIRA Integrada COSTAL ZONE MANAGEMENT

\title{
Design and evaluation of marine and coastal governance indicators for the Southern Mexican region ${ }^{*}$
}

\author{
Isaac Azuz-Adeath $^{\circledR}$, a $;$ César García-Gutiérrez ${ }^{\mathrm{b}}$; Humberto Alonso-Peinado ${ }^{\text {b }}$ Carlos Torres-Navarrete ${ }^{\mathrm{c}}$; \\ Salomón Díaz-Mondragón ${ }^{\mathrm{d}}$
}

\begin{abstract}
This paper presents a set of coastal and marine governance indicators for the southern Mexican coast; this set of indicators was developed as a part of the database, information and knowledge provision for the Regional and Marine Planning Process for six -southern and central- Pacific coastal states (RMPP-SCP). The theoretical framework and methodological approach followed the concepts developed by the Intergovernmental Oceanographic Commission (IOC-UNESCO). The following three different spatial/administrative scales were used: regional, state and county levels. This paper mainly examined the countylevel results. A total of forty-six indicators were created, evaluated and used to define four compound indexes related with the institutional, policy and legal arrangements; the adequacy of the management process; the information, knowledge and participation level and the mainstreaming of the planning proposals, finally, aggregating these four indexes one general governance index for the region was proposed. We explored the internal consistency of the indicators by running several uncertainty analyses that entailed evaluating the effect of the aggregation method, the weighted scheme and the exclusion of individual indicators in the overall performance of the study region and its four dimensions (goals). The general governance index shows only $9 \%(5 / 53)$ of the total counties with a regular/medium governance level and $91 \%(48 / 53)$ with poor/bad governance level. An interesting and expected finding was the observation of a significant correlation between the general governance index and the governmental poverty level index. Using the governance results, the paper proposes several paths to implement the RMPPSCP actions at county or state level; identifies the key elements (i.e. indicators, objectives, goals) to work on them in order to have more chances of success in implementing the program, and the critical variables (related to governance) that need to be improved to maintain or improve the environmental quality of the region. The set of governance indicators could be applied to other regions in the country for promoting integrated coastal and marine planning and management, but also could provide practical benefits for the development of municipalities and states when using them as benchmarking strategies.
\end{abstract}

Keywords: Governance Indicators, Coastal, Marine, Planning Process, Mexico.

\footnotetext{
(a) Corresponding author to whom correspondence should be addressed.

${ }^{a}$ CETYS-University, Center for Higher and Technical Education, Engineering School and Graduate Program in Sustainable Development, Km 1 Camino Microondas, Trinidad S/N, Ensenada, B.C., México. e-mail: Azuz-Adeath <Isaac.azuz@cetys.mx>.

${ }^{\mathrm{b}}$ Atlas Terra Consultores, Ensenada, B.C., México. e-mail: García-Gutiérrez <farallon@hotmail.com>.

${ }^{\mathrm{c}}$ Mexico National Oceanographic Data Center/Institute for Oceanologic Research (UABC), Ensenada, B.C., México. e-mail: TorresNavarrete $<$ ctorres@uabc.edu.mx>.

d Ministry of Environment and Natural Resources (SEMARNAT), Mexico City. e-mail: Díaz-Mondragón <salomon.diaz@semarnat.gob.mx>.
}

* Submission: 16 JAN 2015; Peer review: 24 FEB 2015; Revised: 9 MAY 2015; Accepted: 25 MAY 2015; Available on-line: 1 JUN 2015

This article contains supporting information online at http://www.aprh.pt/rgci/pdf/rgci-578_Azuz-Adeath_Supporting-Information.pdf
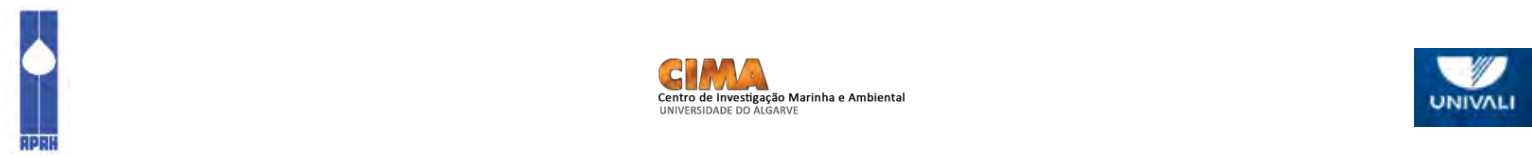


\section{RESUMO $^{\S}$}

Concepção e avaliação de indicadores de governança marinhos e costeiros para a região sul do México

Este trabalho apresenta um conjunto de indicadores de governança costeiros e marinhos para a costa sul do México; este conjunto de indicadores foi desenvolvido como parte da base de dados, informação e conhecimento para o Processo de Planeamento Regional e Marinho em seis estados costeiros, meridionais e centrais, do Pacífico (RMPP-SCP). O referencial teórico e a abordagem metodológica seguiram os conceitos desenvolvidos pela Comissão Oceanográfica Intergovernamental (COI-UNESCO). Utilizaram-se as três escalas espaciais e administrativas seguintes: regional, estadual e municipal. Neste trabalho examinaram-se, principalmente, os resultados a nível municipal. No total, criaram-se, avaliaram-se e utilizaram-se quarenta e seis indicadores para definir quatro índices compostos, relacionados com a) arranjos institucionais, políticos e legais; b) com a adequação dos processos de gestão; c) com a informação, conhecimento e nível de participação; e d) com a integração das propostas de planeamento. Finalmente, estes quatro índices foram agregados por forma a propor um índice geral de governança para a região. A consistência interna dos indicadores foi testada através de várias análises de incerteza, o que implicou avaliar o efeito do método de agregação, o esquema ponderado e a exclusão de indicadores individuais no desempenho geral da região de estudo e as suas quatro dimensões (metas). O índice geral de governança revela que apenas 9\% (5/53) do total de municipios apresentam um nível de governança regular / médio e que 91\% (48/53) têm nível de governança baixo / mau. Um resultado interessante, ainda que esperado, foi a observação de uma correlação significativa entre o índice de governança geral e o indice governamental do nível de pobreza. Utilizando os resultados do índice de governança, propõem-se várias vias para implementar as acções RMPP-SCP a nível municipal ou estadual, identifica os elementos-chave (ou seja, indicadores, objectivos, metas) que devem ser considerados para ter mais hipóteses de sucesso na implementação do programa, e distingue as variáveis críticas (relacionadas com a governança) que precisam ser melhorados para manter ou melhorar a qualidade ambiental da região. O conjunto de indicadores de governança poderá ser aplicado a outras regiões do país para promover o planeamento e a gestão costeira e marinha integrada, mas também pode fornecer beneficios práticos para o desenvolvimento dos municípios e estados ao utilizá-los como estratégias de aferição.

Palavras-chave: Indicadores de Governança, Costeiros, Marinhos, Processo de Planeamento, México.

\section{Introduction}

One of the seven critical issues defined in Rio+20 conference summit was the importance of the world's oceans as a key resource for a sustainable future. In regards to sustainable development goals, one of the conference outcomes established "that progress towards the achievement of the goals needs to be assessed and accompanied by targets and indicators, while taking into account different national circumstances, capacities and levels of development" (UN, 2012).

According to the Organization for Economic CoOperation and Development (OECD, 1993), an indicator can be defined as a parameter or a value derived from other parameters that provide information about a phenomenon. The indicator has significance that extends beyond the properties directly associated with the parameter value. Indicators possess a synthetic meaning and reduce the number of measurements required to present a situation, simplify the process of communicating with users and are developed for a specific purpose. Importantly, an indicator, as a piece of information, is a part of a specific management process and can be compared with the objectives of that management process (Bossel, 1999).

Integrated coastal and marine management plans (Cicin-Sain \& Knecht, 1998), coastal spatial planning (Kay \& Alder, 2005), natural protected area establish- ment or monitoring (Marques et al., 2013), regional sea studies (van Tatenhove, 2013) and Large Marine Ecosystems (LME) analysis (Sherman, 2013) require indicators and reporting technics that reflect the state of the environment, the impact of anthropogenic activities and the performance of the proposed actions, plans and programs among other scientific tools and administrative managerial instruments (Olsen, 2003; Belfiore et al., 2003; Pomeroy et al., 2005; Arceo \& Granados-Barba, 2010).

The use of indicators in the coastal/marine arena goes back to the 90 s with the frameworks provided by GESAMP (1995, 1996), Pacheco (1995), Garcia (1996), Burbridge (1997), Olsen et al. (1997) and Vandermeulen (1998), among others. These frameworks visualize the use of technical tools as a generalized process to assess environmental health and human development trends in marine/coastal areas. Most recently, international indexes and indicators, such as the Global Map of Human Impact on Marine Ecosystems, the Ocean Health Index (Halpern, et al., 2008, 2012) or the Global Coastal Network (Malone et al., 2014) have been developed.

In Mexico, the ministry of environment and natural resources (SEMARNAT) presents several coastal and marine indicators on the national level (SNIASEMARNAT), mostly focused on fisheries, oil process,

\footnotetext{
${ }^{\S}$ Portuguese versions of the abstract and captions by Ana Gomes on behalf of the Editorial Board
} 
tourism, coastal population growth and coral reef behavior, on a yearly basis. Additionally, several integrated assessments and indicators have been developed in the context of the Regional and Marine Planning Processes of the country such as the Gulf of California, Gulf of Mexico and Caribbean Sea, North Pacific and Central and Southern Pacific (SEMARNAT, 2012) and also in international projects on the marine spatial planning of large marine ecosystems (Díaz-de-León \& Díaz-Mondragón, 2013).

At the county level, Seingier et al $(2010,2011)$ created a "sustainability capacity index" and a "coastal orientation" index to assess the state of all the coastal municipalities in the country, and Poncela et al (2012) evaluated a modified human development index through the analysis of local Agenda 21 results for several coastal counties. In the context of climate change, a general framework for the construction of indicators and indices as well a proposed set of them were provided by the National Integrated Coastal and Marine Management Network (Azuz-Adeath et al., 2010 a, b), and for the Caribbean area, some indicators were presented for the National Program for Climate Change Adaptation in Natural Protected Areas (March et al., 2011).

According to Ehler (2003), in the field of integrated coastal management, coastal governance can be defined as the structures and processes used to govern behavior, both public and private, in the coastal area and the resources and activities it contains. Additionally, from the perspective of ecosystem-based management, the use of governance concepts and practices is essential to structure interventions in large marine ecosystems and to build agreements between parties (Duda \& Sherman, 2002; Mahon et al., 2009; Díaz-de-León \& DíazMondragón, 2013). Governance involves setting priorities that may establish hierarchies of interests, but the basis is recognition of what is excluded, as well as what is given priority in certain situations, through public participation and the involving of networks, stakeholders and actors (Sutherland \& Nichols, 2006; Hoefnagel et al., 2013). In these situations, governance indicators may be the right tool to define baselines, evaluate variables and data availability and, monitor processes and achievements.

Coastal and marine governance play a key role in the success of any integrated coastal/marine management plan. Around the world, several coastal and marine indicators that include some type of governance component have been analyzed or applied; in Europe and Northern Africa (Smeets \& Weterings ,1999; Baan et al., 2003; Sardá et al., 2005; Ernoul, 2010; House \& Phillips, 2012); in North and South America (Vandermeulen, 1998; Fontalvo-Herazo et al., 2007); Day and Dobbs (2013) in Australia and Cabral et al. (2013) and Ye et al. (2014) in Asia, among many others. Incorpo- rating elements of governance identified by Ehler (2003), Belfiore et al. (2006) and Silva et al. (2011), the definition of governance that guides this study includes laws, policies, institutions and processes, working in an articulate way towards the proposal, implementation and monitoring of actions affecting social, economic and natural capital in the marine and coastal spaces.

The main objective of this paper is to present and analyses the performance of a set of 46 governance indicators developed for the assessment of the baseline conditions (characterization and diagnosis) in central and southern Mexico's Pacific states and coastal counties as a part of the technical work developed for the Regional and Marine Planning Process (RMPP-CSP) conducted and headed by the Mexican Ministry of Natural Resources (SEMARNAT). Associated with the RMPP-CSP goals, four compound indicators were built to obtain a general or global governance index. In the following section, a description of the study area and the legal framework that supports the planning process will be presented. In the methodology section, we present the structure of the indicators and indexes proposed and evaluated. Finally, we show the results obtained in the assessment process for the coastal-marine governance level in 53 littoral counties and 6 coastal states.

\subsection{Study Area and Legal Framework}

The central and southern Mexican Pacific region comprises 6 coastal states with a terrestrial surface of $373,570 \mathrm{~km}^{2}$, and 53 coastal counties (shown in parentheses for each state), Jalisco (5), Colima (3), Michoacán (3), Guerrero (13), Oaxaca (20) and Chiapas (9); a marine component of $1,206,710 \mathrm{~km}^{2}$ and a total coast length of 2,077 km (see Fig 1).

The total population in the region is $24,339,584$ inhabitants (INEGI, 2010), which corresponds to $21.6 \%$ of the national population. In terms of poverty levels (Estrada et al., 2011), Jalisco and Colima have low levels, Michoacán has a high level, and Guerrero, Oaxaca and Chiapas, the 3 poorest states in Mexico, have very high poverty levels.

The region contributes only $14 \%$ of the national Gross Domestic Product (GDP). The main economic activities are as follows: industry and commerce (Jalisco), tourism (Guerrero, Oaxaca and Chiapas) and agriculture (Michoacán and Jalisco), and three important ports are located in Colima, Guerrero and Chiapas. In general, the natural capital and biodiversity of the study area could be considered one of the biggest in Mexico; the highest numbers of several species in the country (pteridophytes, gymnosperms, angiosperms, amphibious, reptiles, birds and mammals) are located in the region (SEMARNAT, 2014a); the largest densities of endemic species occurred in the study area (Koleff \& Soberón, 2008) and three of seven terrestrial ecoregions of 


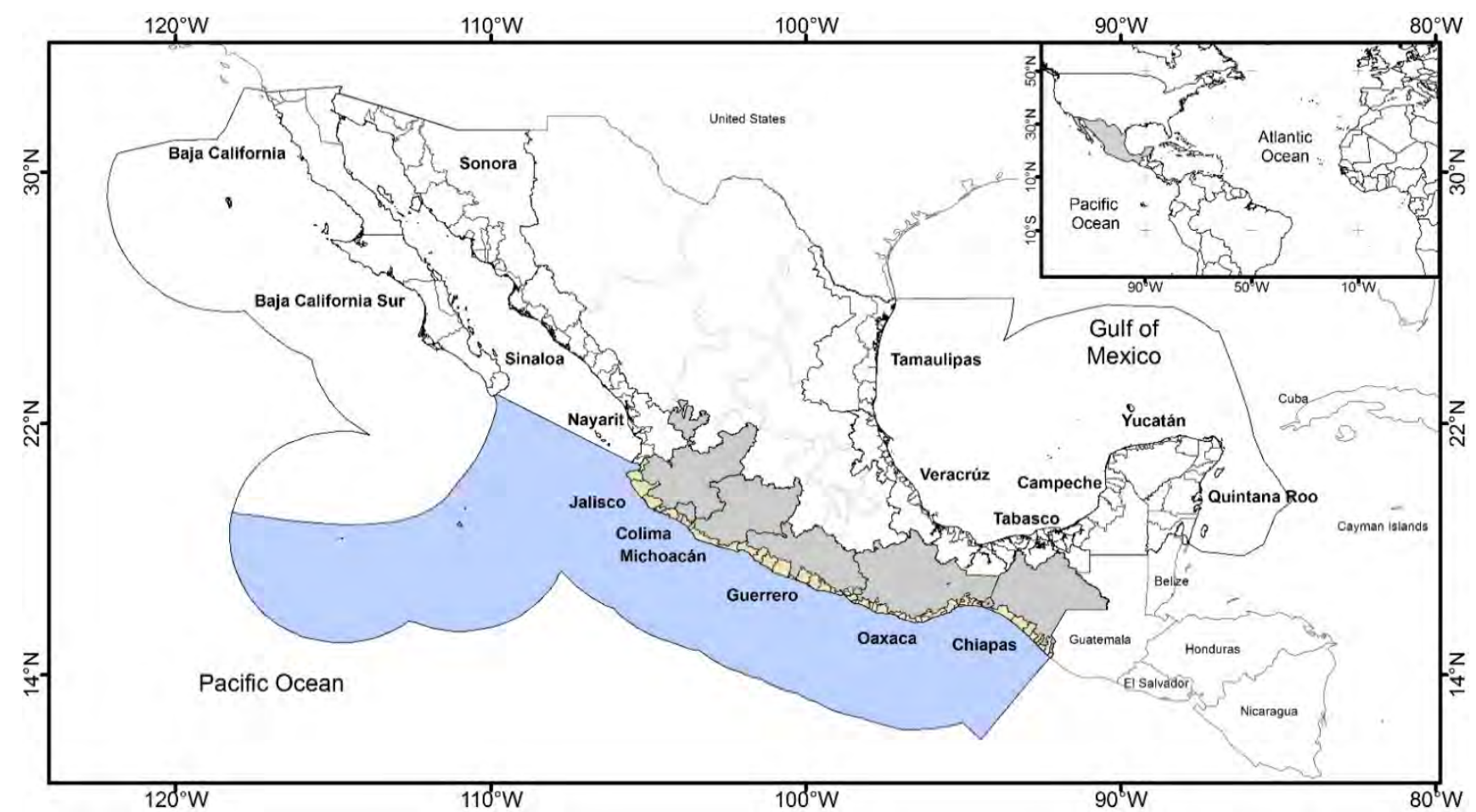

Figure 1 - Study area. Mexico's central and southern Pacific coastal states (gray) and coastal counties (light gray).

Figura 1 - Área de estudo. Estados do México central e sul na costa do Pacífico (cinzento) e municípios costeiros (cinzento claro).

Mexico could be observed (INEGI-CONABIO-INE, 2008). Several recreational beaches recognized worldwide are located in the area, including Costa Alegre (Jalisco), Manzanillo (Colima), Acapulco and Zihuatanejo (Guerrero) and Huatulco bay (Oaxaca), but the region is highly vulnerable to natural phenomena as earthquakes, hurricanes and landslides (SEGOB, SMN).

From a legal and regulatory perspective, marine and coastal areas of Mexico are extremely complex to manage given the diversity of sectoral policy instruments that apply to them. The most important coordination efforts have been taken from the bodies responsible for environmental issues. Recently the National Policy for Seas and Coast (CIMARES, 2012) and the Environmental Policy for Oceans and Coast (SEMARNAT, 2006a) -both instruments defined as a public policiesestablished the basis for the coastal management in Mexico, but until now, the country does not have any mandatory law created specifically for the coastal zone and its management. In the absence of a coastal law or legally defined integrated coastal zone management guidelines, the government and the scientific community have had to resort to the closest related existing instruments to assure coastal and marine sustainability, in this case the spatial planning processes.

The legal basis for the development of any type of territorial land use and planning in Mexico is established in the General Law for the Ecological Equilibrium and Environment Protection (LGEEPA, 1988). This law defines four types of territorial planning processes: gen- eral (for all the national territory), regional (developed by one or more states), local (developed at the county level) and marine (which includes the coastal zone). Any spatial planning process in Mexico must have four steps: characterization, diagnosis, prospective and proposal.

The National Strategy for Land and Sea Planning in Oceans and Coasts (SEMARNAT, 2006b) presented a framework for the development of the marine and coastal planning in different regions of Mexico including the Gulf of California, the Gulf of Mexico and the Caribbean Sea, the Northern Pacific and the Central and Southern Pacific. In all these processes, the central government developed the programs in collaboration with the coastal states and municipalities with strong public participation. At present, the first two programs mentioned are officially decreed and published in the Official Journal of the Federation and the last two are still in process of formulation.

The RMPP-SCP will be a regulatory instrument that will provide:

a) Regional coordination (6 coastal states), understanding and agreement about issues that should be addressed;

b) Enhanced coordination among Federal, State, Municipalities, participatory bodies, and stakeholders on ocean and coastal issues;

c) An instrument to guide and coordinate the Federal, State and County actions in the region; 
d) A participatory arena for acquiring and sharing data and information to help avoid and reduce conflicts.

\section{Methodology}

The Regional and Marine Planning Process for the Southern and Central Pacific coastal states in Mexico (RMPP-SCP) uses the following four types of descriptive indicators: a) ecological, b) social, c) economic and d) governance in the evaluation process of the baseline of the study area using administrative limits at three resolution scales, regional, state and county.

The set of governance indicators presented in this paper was developed as a part of the database, information and knowledge delivery for the RMPP-SCP. All of the indicators and compound indices were mapped in a geographic information system (GIS) to show the preliminary results in public and sectorial participation forums before the integration of the final document. This section is focused only on the methodological process followed in the construction and evaluation of the governance indicators; includes the followed conceptual framework, information about the used data, the variables evaluation procedures, the aggregation and visualization methods, a general description of the proposed governance indicators and information about the internal consistency tests. Figure 2 shows the general steps scheme on the governance indicators structure.
The study region presents insufficiencies in coastal and marine technical information and data availability in comparison with other regions in the country. This fact imposed practical restrictions on the conceptualization, development and assessment of the indicators. Considering these restrictions, some general principles used in the definition of the governance indicators were as follows:

a) Ability to represent the goal and objective for which the indicator was developed in the context of the regional and marine planning process.

b) Availability of official information at county level.

c) Potential for monitoring through time and sensitivity to reflect changes in the governance status.

We must note that during the data acquisition process, political elections were taking place in several states, and some official web pages were not available due to legal regulations, limiting the availability of public information. In these cases, the information and data came directly from the environmental ministry.

Additionally, without any other similar studies working from the municipal to the regional scale, related to marine or coastal governance issues, the performance of the indicators were indirectly contrasted with the official poverty indicators (Estrada et al., 2011), which include health, income, services and educational variables

Regional and Marine Planning Process for the Southern and Central Pacific Coastal States in Mexico (RMPP-SCP)

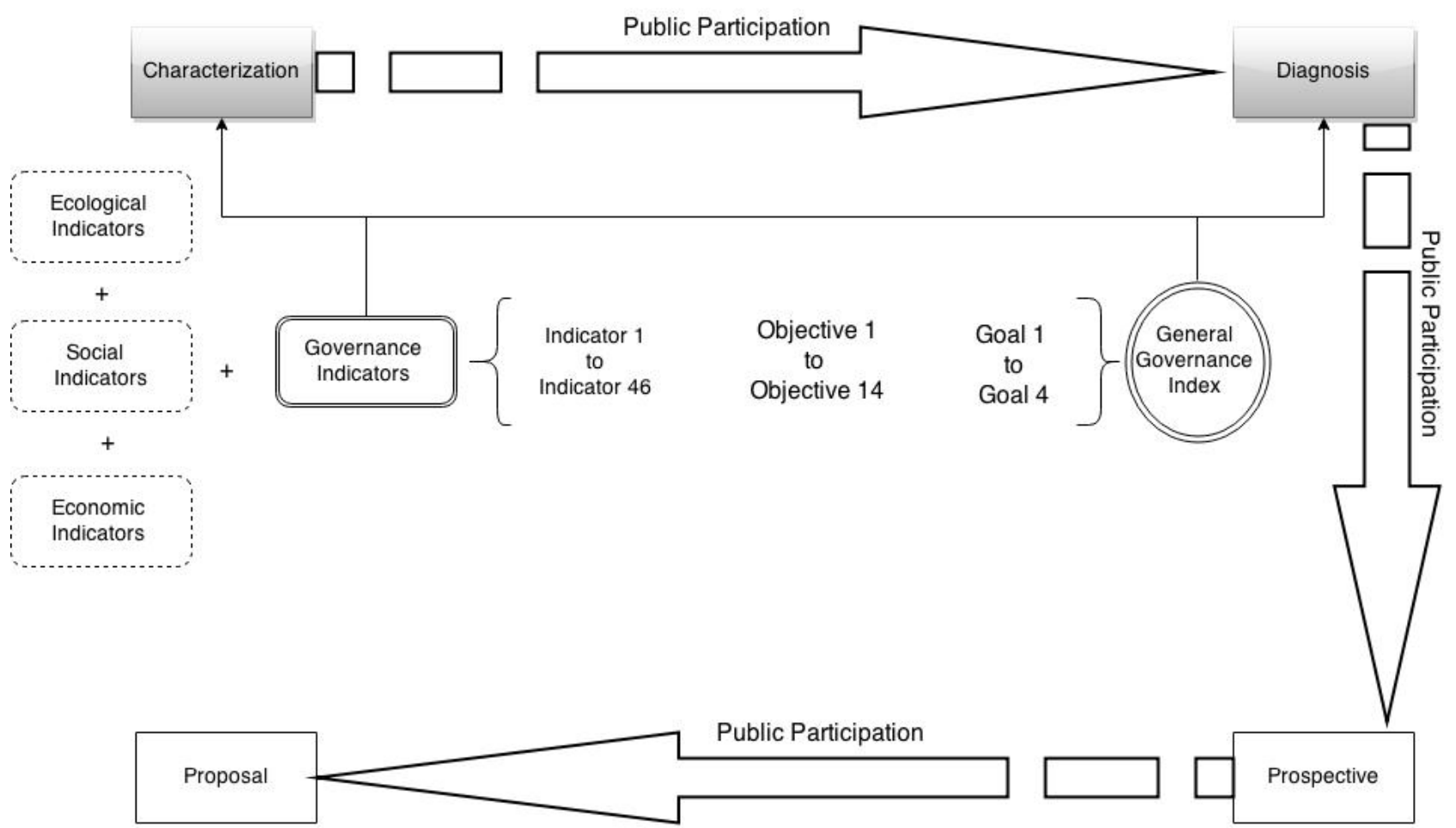

Figure 2 - General scheme of the Regional and Marine Planning Process. The types of indicators used in the characterization and diagnosis stages are presented with especial focus on governance indicators.

Figura 2 - Esquema geral do Processo de Planeamento Regional e Marinho. Os tipos de indicadores utilizados nas fases de caracterização e diagnóstico são apresentados com um enfoque especial nos indicadores de governança. 
under the assumption that higher governance level means better living conditions. Several variables used to build the poverty indicators (Estrada et al., 2011) include elements related with adapted spaces such as cities (e.g. towns with less than 5000 inhabitants), energy and clean water networks (e.g. inhabitants without access to electricity or clean water), and sewage systems (e.g. inhabitants without sewage systems). Furthermore, in order to examine whether the general governance index or its components related to broader measures of coastal and marine health and sustainability, some comparisons with the rate of vegetation loss, mangrove extension, soil degradation and fisheries status were performed for the study region at state level.

\subsection{Conceptual framework}

Several frameworks and guidelines of relevance to integrated coastal zone management have been proposed; the chapter 17 of "Agenda 21" (UN, 1992), the OECD integrated policies for coastal zone management (OECD, 1993), the World Bank guidelines for integrated coastal zone management (Post \& Lundin, 1996), the European code of conduct for coastal zones (EU, 1999), the integrated marine and coastal area management guidelines (CBD, 2004) among others (see Belfiore et al., 2003; 2006).

This study follows the conceptual framework and methodology proposed by the Intergovernmental Oceanographic Commission (IOC-UNESCO) originally established for measuring the progress and outcomes of Integrated Coastal and Ocean Management (Belfiore et al., 2006), but in this research, adapted for a planning process in the Mexican context (e.g. Governmental levels; administrative jurisdictions; legal, regulatory and normative frameworks; participatory bodies and official committees) specifically to obtain governance baseline information as an input for the RMPP-SCP. The use of this framework was defined directly by the Mexican Ministry of Environment.

According to Bossel (1999) indicator sets about a given system are determined by two distinct requirements: (1) they have to provide vital information providing a picture about the current state and corresponding viability of that system; and (2) they have to provide sufficient information about the system's contribution to the performance of other systems that depend on them. This study describe only the baseline or current governance state for the southern and central Pacific Mexican coast as an input for their regional and marine planning process.

Four goals and fourteen objectives were proposed in this study to build forty-six governance indicators. For every coastal county in the region the indicator's variables were measured, grouped by objective, then by goal and finally aggregated to form the general govern- ance index for the study region. All variables, indicators and indices obtained in each municipality were standardized so that the scores were between 0 and 1 , where 0 corresponded to the worst conditions and 1 to the highest standards of governance. With all values ranging from 0 to 1 , a qualitative scale was proposed: "low governance level" (values between 0 to 0.3333 ), "medium governance level" (values between 0.3334 to 0.6666 ) and "high governance level" (values between 0.6667 and 1). Table I shows the goals, objectives and number of indicators used in this research.

\subsection{Database, evaluation, aggregation and visualiza- tion techniques}

The main sources of information and data for the evaluation of the governance indicators were official public sources at the national (federal) level, from the official state and county web pages (if they exist) and through official journals of the federation, states and counties in which the laws and regulations were published.

When working with governance, some variables need to be evaluated in a qualitative way. In this study we used the following types of variables:

a) Dichotomous variables. These variables need to be evaluated by selecting between two alternatives like Yes/No or Exist /Not Exist, etc.

b) Qualitative variables. The options for this type of variable are wider than in dichotomous variables, but the elements under assessment remain qualitative, like Good/Regular/Bad or Started/In Development/Finished, etc.

c) Quantitative variables. These variables use integer numbers (discrete variables), fractional numbers (continuum variables), percentages, ratios, etc.

The following symbols will be used in the indicators tables: "Y/N" for dichotomous variables, "QV" for qualitative variables and "\#” for quantitative variables.

In the indicator-building process, the dichotomous variables take the value of 1 or 0 ; the possible values for qualitative variables are $0,1 / 4,2 / 4,3 / 4$ or $4 / 4$, and the direct scores obtained from quantitative variables were standardize between 0 and 1 based on the following formula: standardized variable $=$ (original variableminimum value) / (maximum value-minimum value).

In the aggregation process (Nardo et al., 2005; OECD, 2008), every group of indicators (grouped according to the corresponding goal) was averaged over all counties with the same weight for each indicator (linear aggregation), and the general governance index was calculated as the mean of the four values associated with each goal. The indicators were developed with a "positive"vision, which means that high values of the indicators are associated with better conditions. When several 
Table I - Summary of governance goals, objectives and total number of indicators defined for the RMPP-CSP.

Tabela I-Resumo das metas de governança, objectivos e número total de indicadores definidos para o RMPP-CSP.

\begin{tabular}{|c|c|c|}
\hline Goal & Objectives & $\begin{array}{l}\text { Number of Indi- } \\
\text { cators for each } \\
\text { objective }\end{array}$ \\
\hline \multirow{4}{*}{$\begin{array}{l}\text { 1. Ensuring adequate } \\
\text { institutional, policy and } \\
\text { legal arrangements }\end{array}$} & 1.1 Ensuring the coordination and coherence of administrative actors and policies & 4 \\
\hline & 1.2 Existence of adequate legislation and regulation & 1 \\
\hline & 1.3 Existence of environmental assessment procedures & 4 \\
\hline & 1.4 Existence of conflict-solving and law enforcement mechanisms & 4 \\
\hline \multirow{4}{*}{$\begin{array}{l}\text { 2. Ensuring adequate } \\
\text { management processes } \\
\text { and implementation }\end{array}$} & 2.1 Managing coastal and marine issues through adequate planning instruments & 4 \\
\hline & 2.2 Implementing and enforcing the actions derived from the planning instruments & 4 \\
\hline & 2.3 Routinely monitoring and evaluating the planning instruments outcomes & 4 \\
\hline & 2.4 Supporting economic and administrative structures & 2 \\
\hline \multirow{4}{*}{$\begin{array}{l}\text { 3. Enhancing informa- } \\
\text { tion, knowledge, aware- } \\
\text { ness and participation }\end{array}$} & 3.1 Ensuring the use of scientific and technical information for decision-making & 3 \\
\hline & 3.2 Ensuring sustained support from engaged stakeholders & 4 \\
\hline & 3.3 Ensuring Non-Governmental Organizations (NGO's) involvement & 1 \\
\hline & 3.4 Ensuring adequate capacitation for the personnel involved & 4 \\
\hline \multirow{2}{*}{$\begin{array}{l}\text { 4. Mainstreaming the } \\
\text { proposals and the eco- } \\
\text { nomic instruments }\end{array}$} & $\begin{array}{l}\text { 4.1 Enabling and support the planning process through environmentally-friendly } \\
\text { technology }\end{array}$ & 3 \\
\hline & 4.2 Incorporating economic instruments into coastal and marine management & 4 \\
\hline
\end{tabular}

years of information were available, and the information provided by the accumulation of values was more appropriate to establish the current conditions, the indicators use the aggregated value of the time series. To visualize the results, a GIS system was developed, and the indicators values and qualitative governance levels were mapped for each one of the indicators and goals at county scale (see supporting information SI.2 to SI.5).

\subsection{Governance indicators}

The set of governance indicators proposed in this study can be understood as a series of elements that determine the state of the region under analysis before implementing the spatial planning program (RMPP-SCP). These indicators establish the baseline for monitoring future efforts and should be understood according to the classification of Ehler (2003) as input-based rather than outcome-based indicators. Besides the framework used (Belfiore et al., 2006), recently other studies have proposed similar indicator measurements systems (Garces et al., 2013; Schernewski et al., 2014; Ye et al., 2014).

Table II presents the set of indicators developed and measured for each goal: goal 1 - "Ensuring adequate institutional, policy and legal arrangements"; goal 2 "Ensuring adequate management processes and implementation"; goal 3 - "Enhancing information, knowledge, awareness and participation"; goal 4 - "Mainstreaming the ordinance proposals and economic instruments".
To "Ensuring adequate institutional, policy and legal arrangements" for the RMPP-SCP, this study proposed 13 indicators related with: the legal support at regional and county level; existence of institutional elements like official networks and governmental commissions; planning instruments and law enforcement mechanisms. To clarify the logic behind the inclusion of some indicators an example is presented.

In order to attain the goal 1 , four objectives were proposed (see Table I); looking at the objective 1.3 "Existence of environmental impact assessment procedures", four indicators were measured (see Table II), one of them has a direct meaning "projects authorized through Environmental Impact Assessment" (1.3.2), the other three can be seen as a complementary tools; specifically the indicator "county surface with mangrove" (1.3.3) is related with objective 1.3 because mangrove is a federal protected species and any kind of development is prohibited in these areas.

The goal 2 "Ensuring adequate management processes and implementation" in the RMPP-SCP has been characterized by the evaluation of 14 proposed indicators (see Table II). Some indicators are related with development and planning programs at county and state level; existence of protected areas; availability of information and monitoring elements and local economic instruments for the implementation stage, such as indicator "existence of county income law" (2.4.1) which provides information on the formal mechanism through 
Table II - The RMPP-CSP core indicator set: 4 goals, 14 objectives and 46 governance indicators.

Tabela II - Conjunto de indicadores para o RMPP-CSP: 4 metas, 14 objectivos e 46 indicadores de governança.

\begin{tabular}{|c|c|c|}
\hline Goal & Objective & $\begin{array}{l}\text { Indicator number, name and valuation method in parenthesis } \\
\text { (QV=Qualitative Variable; \#=Quantitative Variable; } \mathrm{Y} / \mathrm{N}=\text { Dichotomous Variable) }\end{array}$ \\
\hline \multirow{13}{*}{ 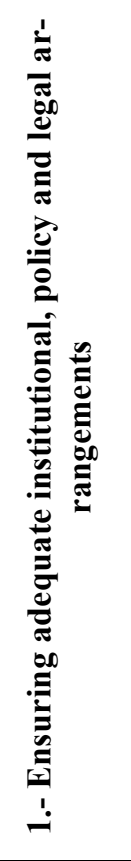 } & \multirow{4}{*}{1.1} & 1.1.1 County participation in local ecological planning process (QV) \\
\hline & & 1.1.2 County participation in regional planning process $(\mathrm{QV})$ \\
\hline & & $\begin{array}{l}\text { 1.1.3 Existence of relevant county commissions (e.g. ecology, territorial planning, water manage- } \\
\text { ment, forestry, beaches management) (\#) }\end{array}$ \\
\hline & & $\begin{array}{l}\text { 1.1.4 County participation in relevant associations or networks (e.g. coastal counties association, } \\
\text { network for counties with ports) }(\mathrm{Y} / \mathrm{N})\end{array}$ \\
\hline & 1.2 & 1.2.1 Relevant county legislation and regulations (e.g. territorial planning, environmental) (\#) \\
\hline & \multirow{4}{*}{1.3} & 1.3.1 Existence of country regulations for wastewaters $(\mathrm{Y} / \mathrm{N})$ \\
\hline & & 1.3.2 Projects authorized trough Environmental Impact Assessment (\#) \\
\hline & & 1.3.3 County surface with mangrove (as a protected species) (\#) \\
\hline & & 1.3.4 Bacteriological quality in county beaches and certificated beaches (\#) \\
\hline & \multirow{4}{*}{1.4} & $\begin{array}{l}\text { 1.4.1 Local land use planning process stage (i.e. without, started, technically finished, legally ap- } \\
\text { proved) (QV) }\end{array}$ \\
\hline & & $\begin{array}{l}\text { 1.4.2 Regional planning process stage (i.e. without, started, technically finished, legally approved) } \\
\text { (QV) }\end{array}$ \\
\hline & & 1.4.3 PROFEPA (Mexico's Environmental Protection Agency) regular visits (\#) \\
\hline & & 1.4.4 PROFEPA (Mexico's Environmental Protection Agency) specific inspections (\#) \\
\hline \multirow{14}{*}{ 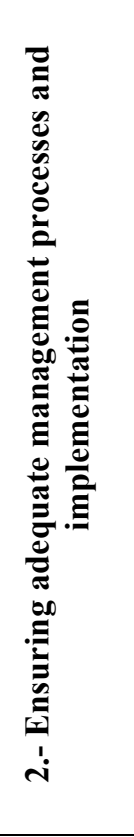 } & \multirow{4}{*}{2.1} & 2.1.1 Existence of county development plans $(\mathrm{Y} / \mathrm{N})$ \\
\hline & & 2.1.2 Existence of local land use plans (legally approved) (Y/N) \\
\hline & & 2.1.3 Existence of regional land use plans (legally approved) $(\mathrm{Y} / \mathrm{N})$ \\
\hline & & 2.1.4 County surface under federal protection (\#) \\
\hline & \multirow{4}{*}{2.2} & 2.2.1 Volume of wastewater treated in the county $(\#)$ \\
\hline & & 2.2.2 Existence of "clean beaches" committees $(\mathrm{Y} / \mathrm{N})$ \\
\hline & & 2.2.3 Existence of certified beaches (as a regulatory instrument) $(\mathrm{Y} / \mathrm{N})$ \\
\hline & & 2.2.4 Existence of RAMSAR sites in the county (as a regulatory instrument) (Y/N) \\
\hline & \multirow{4}{*}{2.3} & 2.3.1 Existence of public GIS systems with county level information $(\mathrm{Y} / \mathrm{N})$ \\
\hline & & 2.3.2 Existence of certified beaches (as a monitoring element) $(\mathrm{Y} / \mathrm{N})$ \\
\hline & & 2.3.3 Existence of RAMSAR sites in the county (as a monitoring instrument) $(\mathrm{Y} / \mathrm{N})$ \\
\hline & & 2.3.4 County surface under federal protection (as a monitoring instrument) $(\mathrm{Y} / \mathrm{N})$ \\
\hline & \multirow{2}{*}{2.4} & $\begin{array}{l}\text { 2.4.1 Existence of county income law (potential to support managerial economic and administrative } \\
\text { structures in the county) }(\mathrm{Y} / \mathrm{N})\end{array}$ \\
\hline & & $\begin{array}{l}\text { 2.4.2 County expenditure per capita per county surface (potential to support managerial economic } \\
\text { and administrative structures in the county) (\#) }\end{array}$ \\
\hline \multirow{8}{*}{ 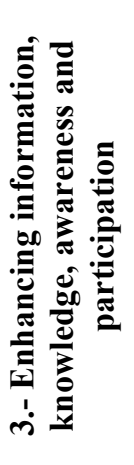 } & \multirow{3}{*}{3.1} & $\begin{array}{l}\text { 3.1.1 Universities and research centers in the county -marine related- as a scientific and technical } \\
\text { providers (\#) }\end{array}$ \\
\hline & & 3.1.2 Research centers for fisheries in the county as a scientific and technical providers (\#) \\
\hline & & 3.1.3 Existence of risk plans for the county $(\mathrm{Y} / \mathrm{N})$ \\
\hline & \multirow{4}{*}{3.2} & 3.2.1 Members of the council for sustainable development in the county (\#) \\
\hline & & 3.2.2 Existence of relevant councils and commissions in the county administration $(\mathrm{Y} / \mathrm{N})$ \\
\hline & & 3.2.3 Existence of official web page in the county (operating) $(\mathrm{Y} / \mathrm{N})$ \\
\hline & & 3.2.4 Potential for public information access $(\#)$ \\
\hline & 3.3 & 3.3.1 Registered environmental related $\mathrm{ONG}^{\prime} \mathrm{s}$ in the county (\#) \\
\hline
\end{tabular}


3.4.1 Education commission in the county administration (\#)

3.4

3.4.2 Universities and research centers in the county -marine related- as a potential capacity building bodies (\#)

3.4.3 Research centers for fisheries in the county as a potential capacity building bodies (\#)

3.4.4 Existence of prevention of risk programs in the county $(\mathrm{Y} / \mathrm{N})$

4.1.1 Number of Eolic power plants in the county (\#)

4.1 4.1.2 Number of hydroelectric power plants in the county (\#)

4.1.3 Beneficiaries from the energy saving program in aquaculture in the county (\#)

4.2.1 Payments from ecological services in the county (\#)

4.2

4.2.2 Beneficiaries from social programs (poverty eradication) in the county (\#)

4.2.3 Payments associated with coastal zone concessions in the county (\#)

4.2.4 Economic resources from the National Disasters Found applied in the county (\#)

which financial resources could be applied to the RMPP-SCP at county level.

The goal 3 "Enhancing information, knowledge, awareness and participation", has been evaluated using 12 indicators (see Table II) associated with the academic and research capacities in the region; NGO's presence; participatory bodies and access to public information.

The most challenging goal in the indicator's construction process was "Mainstreaming the planning proposals and economic instruments" since the original framework (Belfiore et al., 2006) has been developed for the assessment of operating Integrated Coastal Area Management plans. In the present study the indicators were used for the assessment of the baseline conditions (characterization and diagnosis) for the RMPP-SCP.

The goal 4 in this paper includes only two of the three objectives proposed originally by Belfiore et al. (2006), which were associated with the existence of environmentally-friendly technology and the incorporation of economic instruments into coastal and marine management. For this goal, 7 indicators were measured, 2 of them related with the operation of environmentallyfriendly technology in the region and the rest of them have to do with economic programs currently running.

It is important to note that some indicators could be perceived as redundant, such as the use of "research centers for fisheries in the county". This indicator was used in the goal "Ensuring the use of scientific and technical information for decision-making" because we considered the research centers a natural technical information source, but we also use the same variable as a potential capacitating provider in the goal "Ensuring adequate capacitating for the personnel involved". In the future, these types of indicators need to be redefined. For example, at some point, the spatial planning program will be in its implementation phase and then we could not only measure the capacitating potential of the research centers but also have the opportunity to monitor the number of taught courses, the number of students by cohort or the number of graduates.

The detailed explanation of each indicator and the rationale behind its selection and construction, can be seen in Supporting Information SI.I.

\subsection{Indicator's scale sensitivity and internal consis- tency}

Many environmental problems are characterized by complex and dynamic interdependencies across scales and levels (Termeer \& Dewulf, 2014). The concept of scale as a basis for scale-sensitive governance was recently reviewed in theoretical form by Padt \& Arts (2014) and in a practical manner by Schraad-Tischler (2014). In the field of environmental governance, traditionally two scales are used, spatial and temporal, but Cash et al. (2006) made an important contribution by identifying specific governance scales incorporating jurisdictional or administrative, institutional, management, knowledge and social networks and also outlining an interactions typology that includes cross-level, crossscale, multilevel and multiscale interactions.

In this study, we followed the theoretical framework proposed by the Intergovernmental Oceanographic Commission (IOC-UNESCO), assuming that its quality has been tested and proven at the international, regional and national level (Belfiore et al., 2003; Belfiore et al., 2006; Souto, 2014). To assess the overall quality of the compound indicators or indexes proposed in this study, we analyzed the soundness of the procedures used in its construction by considering different weight and aggregation methods, modeling data error and excluding several indicators. The data standardization procedure MinMax (0-1) was adopted as a political and technical decision at the launch of the study, and no further tests were performed.

Following Nardo et al. (2005), OECD (2008) and Charron (2010), we performed a sensitivity and uncertainty 
analysis to gauge the robustness and internal consistency of the composite indicators obtained. Two aggregation methods were tested, linear and geometric, as were two weighting schemes, equal weights and weights according the results of factor and principal component analysis and several tests on data exclusion using the 14 groups of indicators were performed.

\section{Results}

\subsection{Efficiency and robustness of the indicators}

As a first-order outcome, the proposed set of indicators, compound indexes and general governance index for the Mexico's Southern and Central Pacific planning processes has been very suitable in the characterization and diagnostic stages. The model provides valuable information about the governance's baseline and could be useful for monitoring the progress of the RMPP-SCP program during and after its implementation.

Indicators that can be used to map institutional, managerial, participatory and mainstreaming elements related to the RMPP-SCP have been defined at the county, state and regional levels through four analysis dimensions (goals) and fourteen indicator groups (objectives). In this way, the model could be useful in comparing sub-national and regional behavior.

Several test cases were performed to check the internal consistency of the indicator set. In all tested cases, the general governance index for the region remained at the same low qualitative level. We explore different aggregation and weighting schemes which include equal weighting, linear (LIN), geometric (GEO) and weighting according with factor analysis and principal component results (PCA); also we test the effect of exclusion one objective at time. The average relative error for all the tested cases was 7.7\% (see Supporting Information SI.1). Using these results we adopt the linear aggregation method to build the general governance index and the compound indicators (for goals and objectives).

The greater difference between aggregation and weighting methods occurred when we used geometric aggregation with the equal-weight scheme. The highest sensitivity to data exclusion occurred when we removed the indicators related to the existence of a county income law and county expenditure per capita per county surface area. The lowest sensitivity to data exclusion appeared with the exclusion of indicators which describe the existence of universities, research centers (marinerelated), research centers in fisheries and risk plans in the county (see Supporting Information SI.II).

\subsection{Region-specific outputs}

The region under analysis comprises 6 coastal states and 53 littoral counties. After the assessment of 46 governance indicators in each municipality, the results show a very low general governance level 0.1997 (0 to 1 scale). Only five counties present "medium" governance level in the general index.

Considering all the municipalities scores, the best conditions of governance are associated with goal 1 "Ensuring adequate institutional, policy and legal arrangements" $(\mathrm{G}=0.2649)$. To this goal, the most favorable conditions of governance are observed in objective 1.3 "Existence of environmental impact assessment procedures" $(\mathrm{G}=0.4233)$ wherein the indicator 1.3.2 "Projects authorized trough Environmental Impact Assessment" shows the highest score $(\mathrm{G}=0.8859)$, for this indicator 50 counties can be qualified with high levels of governance, reinforcing the fact that EIA is a well-established regulatory instrument in Mexico.

Looking at each goal, the lowest value of governance was obtained in goal 4 "Mainstreaming the ordinance proposals and the economic instruments" $(\mathrm{G}=0.1617)$, for which only one county presented medium qualifications; the rest of them presented low levels. For this goal, the lowest score comes from objective 4.1 "Enabling and support the planning process through environmental-friendly technology" $(\mathrm{G}=0.0377)$ in which the worst evaluated indicator was the "number of Eolic plants in the county" $(\mathrm{G}=0.0189)$. Only for goal 3, "Enhancing information, knowledge, awareness and participation" two municipalities present "high" values of governance, but the general average was $(\mathrm{G}=0.1708)$.

Figure 3 and supporting information SI.6, displays the behavior of general governance index, which shows the aggregate information of the four goals for every county in the study region.

The individual behavior of each county can be seen in Table III and supporting information SI.7. Only Manzanillo, in Colima state, presents values greater than 0.3333 for all the goals, which means that in general this county presents medium to high level of governance.

According with Charron et al. (2010) there is a general acceptance among scholars and policy-makers as to the crucial role of government institutions for the welfare of its citizens and also, good governance is seen as a necessary requirement for countries to foster economic development (Rothstein \& Teorell, 2008) and environmental sustainability (Welsch, 2004; Morse, 2006). In this respect, by way of a comparative analysis, we used official information about the poverty level at county scale (Estrada et al., 2011) to search for a relationship with the general governance index obtained by averaging the results for the four goals in each county. A significant, direct linear relationship $(\mathrm{r}=0.65)$ was found between the poverty level and the governance stage, indicating that better conditions in the county (low poverty) are associated with high levels of governance and vice versa (see Figure 4). 


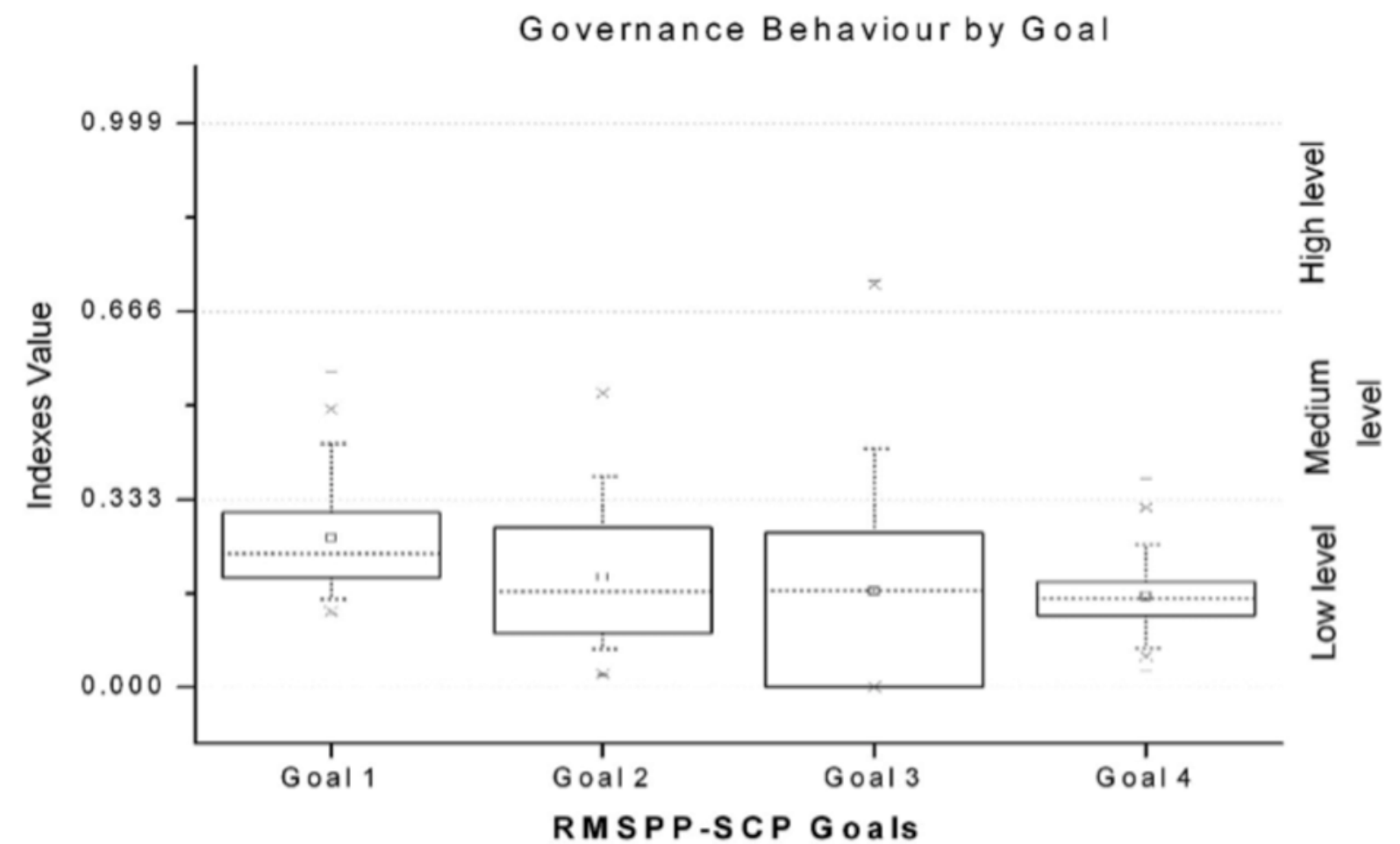

Figure 3 - Governance indicator performance for each goal, using all the coastal counties in the study region.

Figura 3 - Desempenho do indicador de governança para cada meta, usando todos os municípios costeiros na região de estudo.

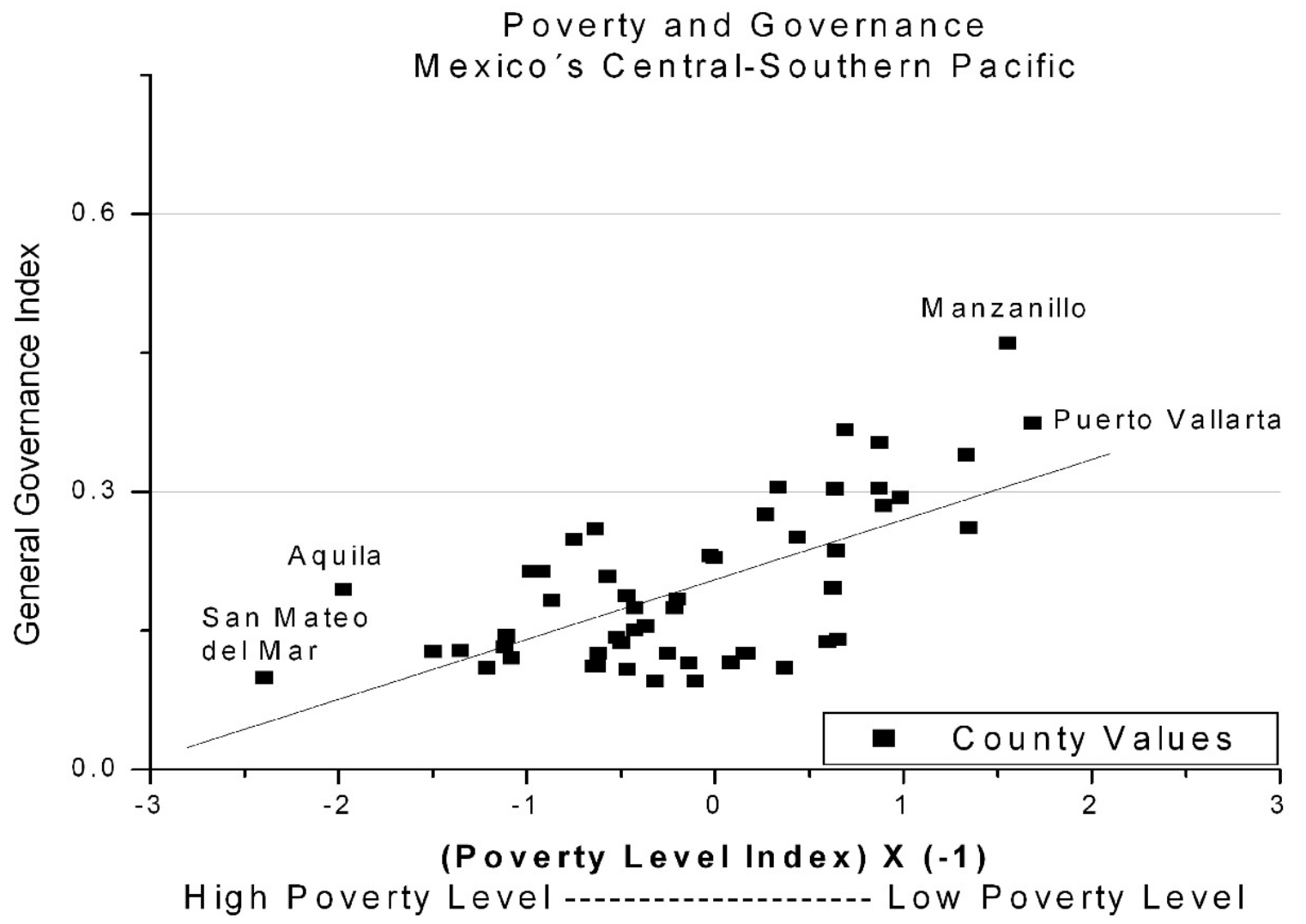

Figure 4 - Comparison between the global governance and poverty level for all the coastal counties in the study region.

Figura 4 - Comparação entre a governança global e o nível de pobreza para todos os municípios costeiros na região de estudo. 
Table III - Summary of governance indicators assessment for the study region ( $0=$ lowest to $1=$ highest governance score).

Tabela III - Resumo da avaliação dos indicadores de governança para a região de estudo ( $0=$ menor a $1=$ maior pontuação de governação).

\begin{tabular}{|c|c|c|c|c|c|c|}
\hline State & County & Goal 1 & Goal 2 & Goal 3 & Goal 4 & General \\
\hline \multirow{5}{*}{ Jalisco } & Puerto Vallarta & 0.3853 & 0.5211 & 0.3731 & 0.2165 & 0.3740 \\
\hline & Cabo Corrientes & 0.4005 & 0.3122 & 0.1948 & 0.1940 & 0.2754 \\
\hline & Tomatlán & 0.4642 & 0.3619 & 0.2353 & 0.1573 & 0.3047 \\
\hline & La Huerta & 0.3654 & 0.2430 & 0.1910 & 0.1463 & 0.2364 \\
\hline & Cihuatlán & 0.4928 & 0.2211 & 0.3850 & 0.0753 & 0.2935 \\
\hline \multirow{3}{*}{ Colima } & Manzanillo & 0.3891 & 0.3681 & 0.7136 & 0.3708 & 0.4604 \\
\hline & Armería & 0.4164 & 0.3239 & 0.4956 & 0.2309 & 0.3667 \\
\hline & Tecomán & 0.3930 & 0.1638 & 0.4174 & 0.2401 & 0.3036 \\
\hline \multirow{3}{*}{ Michoacán } & Coahuayana & 0.2844 & 0.1994 & 0.0130 & 0.0557 & 0.1381 \\
\hline & Aquila & 0.3208 & 0.2325 & 0.1000 & 0.1244 & 0.1944 \\
\hline & Lázaro Cárdenas & 0.5590 & 0.3675 & 0.2430 & 0.1895 & 0.3398 \\
\hline \multirow{13}{*}{ Guerrero } & La Unión de Isidoro Montes & 0.1620 & 0.0227 & 0.0433 & 0.3193 & 0.1368 \\
\hline & Zihuatanejo de Azueta & 0.3977 & 0.3739 & 0.3035 & 0.0644 & 0.2849 \\
\hline & Petatlán & 0.2165 & 0.1051 & 0.0312 & 0.1094 & 0.1155 \\
\hline & Técpan de Galeana & 0.2349 & 0.0966 & 0.2260 & 0.1411 & 0.1746 \\
\hline & Coyuca de Benítez & 0.2830 & 0.2202 & 0.2816 & 0.2525 & 0.2593 \\
\hline & Acapulco de Juárez & 0.3100 & 0.2826 & 0.7208 & 0.0992 & 0.3532 \\
\hline & Benito Juárez & 0.2477 & 0.0692 & 0.0372 & 0.1491 & 0.1258 \\
\hline & San Marcos & 0.2115 & 0.1455 & 0.3249 & 0.1751 & 0.2142 \\
\hline & Florencio Villarreal & 0.1938 & 0.0918 & 0.2611 & 0.2045 & 0.1878 \\
\hline & Copala & 0.1642 & 0.0752 & 0.0251 & 0.1682 & 0.1082 \\
\hline & Cuajinicuilapa & 0.2431 & 0.1860 & 0.2580 & 0.1469 & 0.285 \\
\hline & Marquelia & 0.1562 & 0.1732 & 0.2750 & 0.1318 & 0.1840 \\
\hline & Juchitán & 0.1350 & 0.0212 & 0.2810 & 0.1402 & 0.1443 \\
\hline \multirow[t]{17}{*}{ Oaxaca } & Juchitán de Zaragoza & 0.2165 & 0.0721 & 0.2555 & 0.2402 & 0.1961 \\
\hline & San Dionisio del Mar & 0.1672 & 0.0741 & 0.1111 & 0.1768 & 0.1323 \\
\hline & San Francisco del Mar & 0.1910 & 0.0680 & 0.0000 & 0.1868 & 0.1115 \\
\hline & Santo Domingo Tehuantepec & 0.2057 & 0.1317 & 0.0000 & 0.1007 & 0.1095 \\
\hline & Santiago Pinotepa Nacional & 0.1660 & 0.1346 & 0.0000 & 0.0831 & 0.0959 \\
\hline & Santiago Jamiltepec & 0.1603 & 0.853 & 0.0000 & 0.1363 & 0.0955 \\
\hline & Santo Domingo Armenta & 0.1474 & 0.0982 & 0.0000 & 0.1938 & 0.1098 \\
\hline & Salina Cruz & 0.2995 & 0.2912 & 0.4236 & 0.0294 & 0.2609 \\
\hline & Santiago Tapextla & 0.1583 & 0.2318 & 0.0000 & 0.1185 & 0.1271 \\
\hline & San Mateo del Mar & 0.1303 & 0.0852 & 0.0000 & 0.1809 & 0.0991 \\
\hline & Santa Maria Huazolotitlán & 0.1834 & 0.1011 & 0.0000 & 0.1603 & 0.1112 \\
\hline & Villa de Tututepec de Melchor Ocampo & 0.2582 & 0.0255 & 0.2733 & 0.1400 & 0.1743 \\
\hline & San Pedro Huamelula & 0.2780 & 0.0838 & 0.0000 & 0.1398 & 0.1254 \\
\hline & San Miguel del Puerto & 0.2121 & 0.0956 & 0.0000 & 0.1740 & 0.1204 \\
\hline & Santiago Astata & 0.2200 & 0.1133 & 0.0000 & 0.1270 & 0.1151 \\
\hline & San Pedro Mixtepec - Distr. 22 & 0.2211 & 0.1573 & 0.1111 & 0.0730 & 0.1406 \\
\hline & Santa María Huatulco & 0.2738 & 0.5277 & 0.3409 & 0.0688 & 0.3028 \\
\hline
\end{tabular}




\begin{tabular}{lllllll}
\hline \multirow{7}{*}{ Santa María Colotepec } & 0.2262 & 0.1576 & 0.0000 & 0.1187 & 0.1256 \\
\cline { 2 - 6 } & Santa María Tonameca & 0.2542 & 0.0889 & 0.0000 & 0.1695 & 0.1281 \\
\cline { 2 - 6 } Chiapas Pedro Pochutla & 0.2002 & 0.1543 & 0.1111 & 0.1358 & 0.1504 \\
\hline \multirow{7}{*}{ Sonalá } & 0.4315 & 0.2943 & 0.1715 & 0.2513 & 0.2871 \\
\cline { 2 - 6 } & Pijijiapan & 0.3699 & 0.2548 & 0.0000 & 0.1826 & 0.2018 \\
\cline { 2 - 7 } & Mapastepec & 0.2366 & 0.2098 & 0.0000 & 0.1728 & 0.1548 \\
\cline { 2 - 7 } & Acapetahua & 0.2567 & 0.2908 & 0.0000 & 0.1821 & 0.1824 \\
\cline { 2 - 7 } & Villa Comaltitlán & 0.2056 & 0.2745 & 0.1910 & 0.1856 & 0.2142 \\
\cline { 2 - 7 } & Huixtla & 0.2653 & 0.3225 & 0.1867 & 0.1403 & 0.2287 \\
\cline { 2 - 7 } & Tapachula & 0.2567 & 0.2033 & 0.2632 & 0.2798 & 0.2507 \\
\cline { 2 - 6 } & Mazatán & 0.2304 & 0.3994 & 0.1820 & 0.1803 & 0.2480 \\
\hline
\end{tabular}

Due to lack of information for the region, it was difficult to examine whether the general governance index or its components related to broad measures of coastal and marine health and sustainability. To address this problem, some variables were used to define the environmental quality of the region: the rate of natural vegetation loss (1993 to 2011), soil degradation (2002 to 2010), mangrove areas (CONABIO, 2009), fisheries and aquaculture status (CONAPESCA, 2013) and bacteriological quality of the coastal waters (SEMARNAT, 2014b).

The highest value of the general governance index is given in the state of Colima; this state presents the largest fisheries catch and the second major mangrove density in the littoral zone on the region. The second state with the highest governance index is Jalisco in which the highest rate of soil conservation is presented. The lowest rate of natural vegetation conservation occurs in Oaxaca which is the state with the lower governance score. In the case of Michoacan, a state with "low governance level", the worst environmental conditions are present. The relationships between governance level and environmental quality for all the states in the region can be observed as supporting information (SI.8).

Analyzing the state level behavior (Figure 5), Jalisco and Colima, the northern states in the region, present the highest values of governance $(\mathrm{G}=0.2968$ and $\mathrm{G}=0.3769$ respectively). The counties with the highest governance values are Puerto Vallarta in Jalisco and Manzanillo in Colima. The first is a tourist port while the second, in addition to tourism presents important fisheries. The lowest governance values can be found in Oaxaca and Guerrero $(\mathrm{G}=0.1416$ and $\mathrm{G}=0.1921$ respectively). In these states, Copala in Guerrero and Santiago Jamiltepec in Oaxaca were ranked with the lowest governance scores.

With exception of the State of Chiapas, in all other states in the region the highest governance values occur in municipalities with tourist or commercial ports; Puerto Vallarta in Jalisco, Manzanillo in Colima, Lazaro Cardenas in Michoacan, Acapulco in Guerrero and Santa Maria Huatulco in Oaxaca, showing a clear relationship between economic development and governance. The natural vegetation conservation for these counties is almost the same that the observed average for the region and the soil degradation was $8 \%$ below the regional mean.

The top $10 \%$ of counties with better governance conditions occur in Jalisco (2), Colima (2), Michoacán (1) and Guerrero (1). The bottom $10 \%$ of counties with poorest governance conditions takes place in Guerrero (1) and Oaxaca (5). Figure 6 displays the general results at county level

\subsection{Elements for planning practice towards local to regional sustainability}

How can the governance indicators improve the deploying strategies process for the RMPP-SCP? To answer this question we need to be clear about one of the most complex element in the decision-making process: if the success of the RMPP-SCP implementation depends on the governance level, is imperious improve its actual level, but with limited resources (money, time, capacities) the decision-maker need to choose between start the instrumentation process in the more or in the less developed places. In this sense, the indicators presented in this paper may be useful to allow analyzing critical planning paths, working from different scales (county, state and region) and using information from indicators, RMPP-SCP planning objectives and goals.

If we use the indicator results starting with the worst governance conditions, Oaxaca can be identified as the state with the lowest governance level in the region $(\mathrm{G}=0.1416)$. Inside Oaxaca, the minimum governance score was observed in the municipality of Santiago Jamiltepec $(\mathrm{G}=0.0955)$ in which the major problem was 


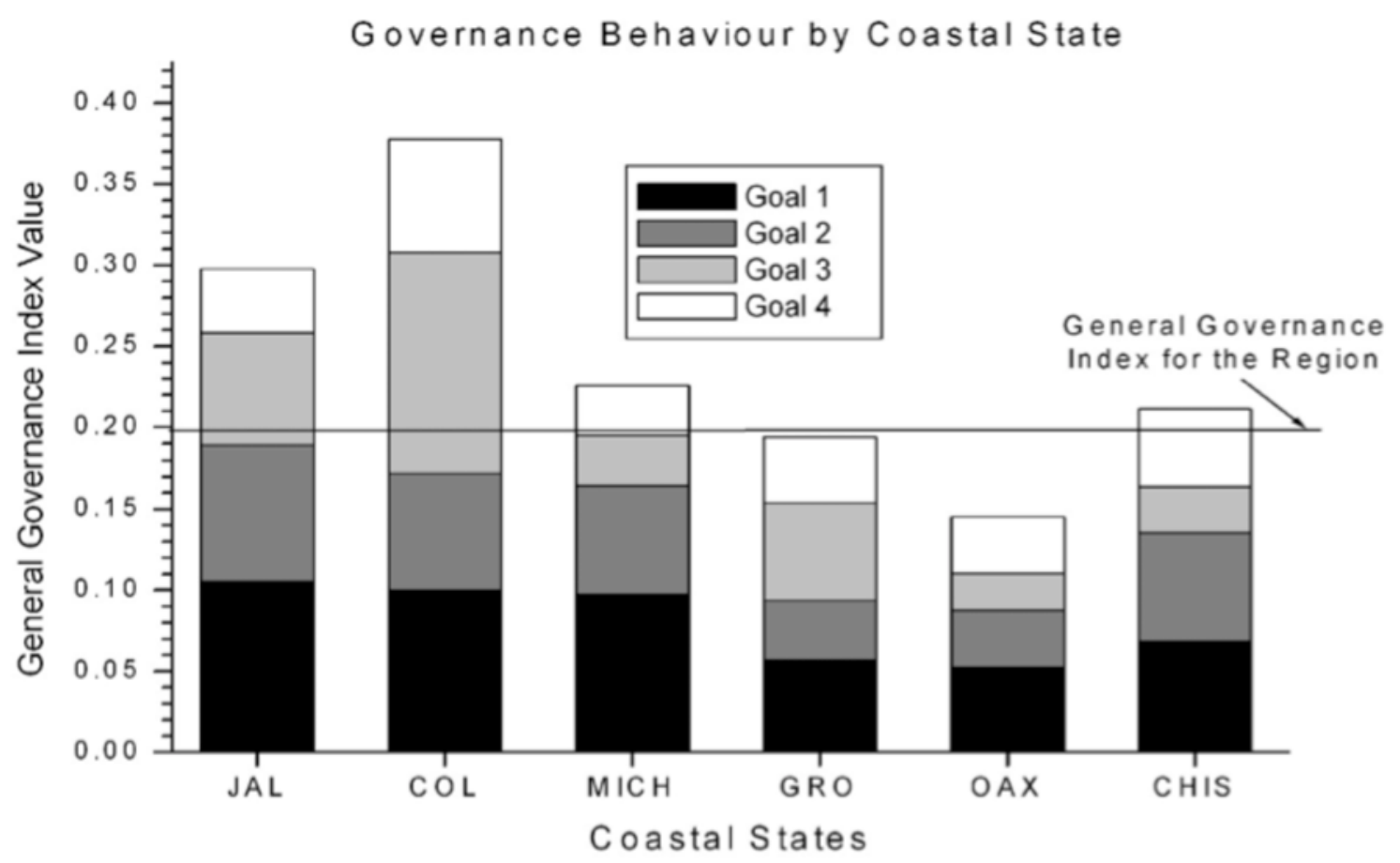

Figure 5 - Governance indicator performance by goal, for each coastal state in the study region.

Figura 5 - Desempenho do indicador de governança por meta, para cada estado costeiro na região de estudo.

detected in the goal 3 "Enhancing information, knowledge, awareness and participation"; all the indicators associated with this goal presented the lowest values. Of the 12 indicators defined within this goal, at least 3 or 4 can be assisted with the RMPP-SCP program to improve the governance of the municipality (e.g. the development of risk plans and risk prevention programs for the county, promoting linking actions with universities and research centers, supporting actions from NGO's in the county).

In the other hand, if we apply the results to the top rated states, counties and attributes to maintain its general quality, the general governance index show Colima as the best evaluated state $(\mathrm{G}=0.3769)$ in order to improve its "medium" governance level, the RMPP-SCP program needs to work in goal 4 (the lowest dimension's score for Colima), by example proposing Eolic farms areas in the state (the lowest scored indicator for the goal 4) or more specifically in Tecoman county, because is the last scored municipality in Colima.

Another approach for the use of governance indicators in the RMPP-SCP could be based in the environmental quality of the region. Using this approach a similar paradigm appears; the efforts and actions need starting in counties or states with good environmental quality or in places with degraded environment? Choosing any of the two options imply that the authorities need to define if they start to work with states or counties with high or low governance.

For the study region, in the best-case scenario path (i.e. good environmental quality and high governance level), the actions of the RMPP-SCP need to start in Chiapas (best environmental quality) and within Chiapas in Tonala municipality (highest general governance index $\mathrm{G}=0.2871$ ).

The best governance score in Tonala occurs in the goal 1 "Ensuring adequate institutional, policy and legal arrangements" inside this dimension two indicators related to ecological and land use planning process presented the best evaluation, under these conditions is highly likely that the RMPP-SCP be successful by following this path. Following the worst-case scenario path (i.e. bad environmental quality and low governance level), the RMPP-SCP efforts and actions need to be focused in Michoacan State (poorest environmental quality) and within Michoacan in Coahuayana municipality (lowest general governance index $\mathrm{G}=0.1381$ ). The lowest governance scores in Coahuayana were obtained in goals 3 and 4; in these two dimensions several indicators present the minimum qualification. The RMPP-SCP needs to apply continual efforts in this county and state to improve their governance and environmental quality.

\section{Conclusions}

The central and southern Mexican Pacific region is rich in natural resources, with a relatively unexploited coastal area, but with the highest levels of poverty in the country, coupled with a lack of scientific and technical capabilities. In this context, the possibility of implementing successful planning actions is based largely on the current status of their governance level. The pro- 


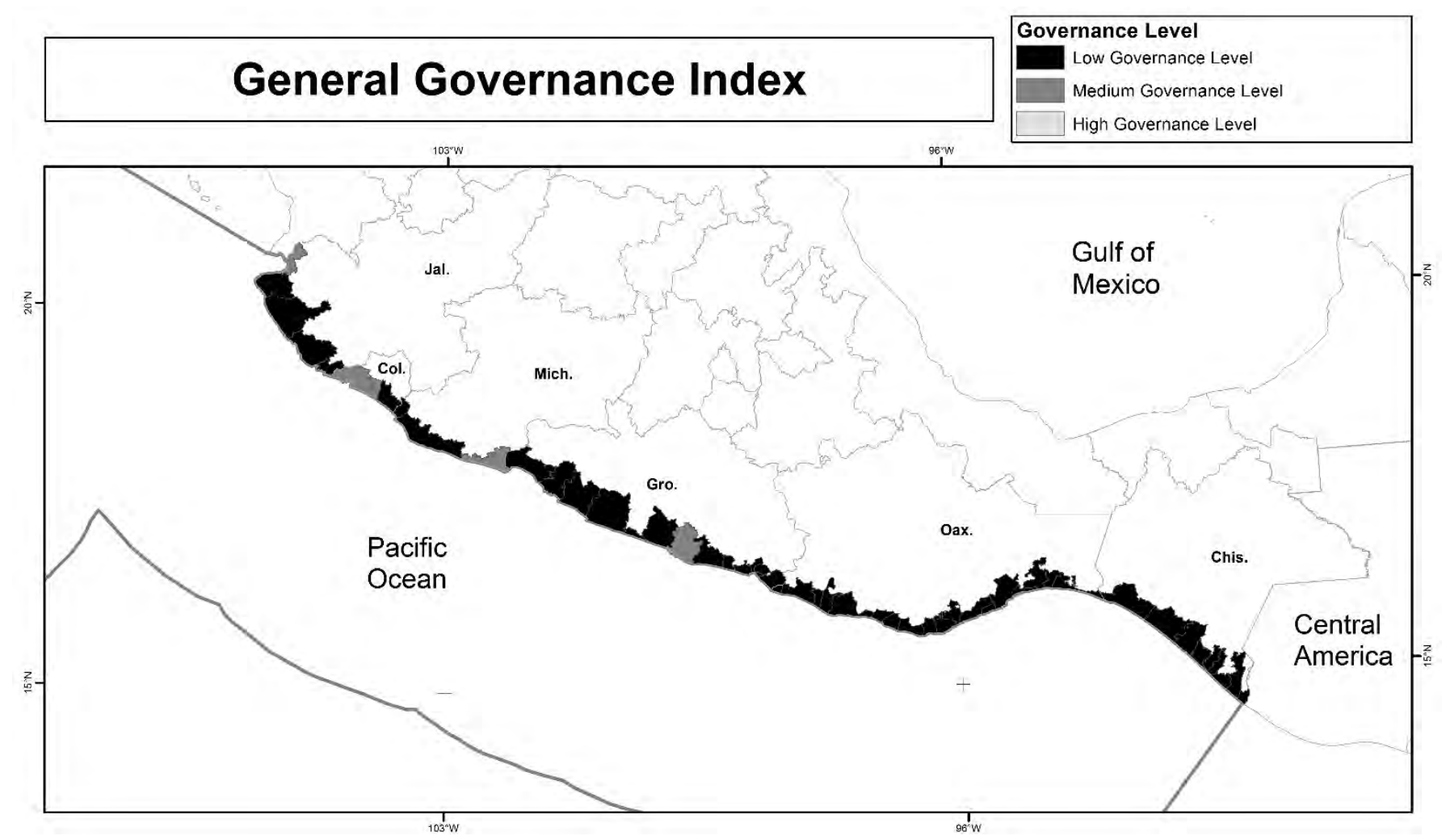

Figure 6 - Results from the general governance index, for each county in the study region.

Figura 6-Resultados do índice geral de governança, para cada município na região de estudo.

posed set of indicators provides an overview of the conditions of governance and identifies the variables and indicators that should be improved in each county to succeed in the implementation of the RMPP-SCP objectives and goals.

A set of 46 governance indicators at county level were created and evaluated in the context of the RMPP-SCP following the framework proposed by the IOCUNESCO (Belfiore et al., 2006) but adapted for the Mexican context in terms of variable selection, with good results. This study has proved that the proposed set of indicators is effective to establish the governance level of the study region, and states and coastal municipalities that comprise it. Of the six states that share the region just one presents medium or regular governance conditions and within the counties analyzed, only five has the same qualification ( $9 \%)$, the rest of states and counties can be characterized by poor governance conditions.

Internal consistency of the general governance index and their compound dimensions (goals) was checked using principal component analysis. The impact of the 4 goals and the 14 objectives on the overall index and the associated error was also evaluated. Sensitivity analysis suggested that the use of a linear aggregation scheme with equal weight was suitable for the general governance index evaluation after standardization of the indicator values $(0-1)$. The validity of the governance index as an element to measure the coastal and marine health and sustainability was difficult to establish, due the lack of environmental information at county level. Using two of the available variables (i.e. natural vegetation cover and soil degradation) we can say that some of the counties located in the highest percentiles of the governance distribution, they are also in the top rank of the stated variables.

A major advantage of the proposed set of indicators is that their assessment does not depend on the perception of participants and stakeholders (through surveys or interviews). In this study, public participation processes were used to validate the scores and not to generate them. Moreover, its biggest disadvantage or weakness occurs when evaluating the existence of elements associated with the governmental or managerial structure (e.g. number of commissions), because they do not take into account whether the commission operates well or not, only quantifies its existence. As a future line of work these elements must be refined.

These governance indicators could be very useful to compare the temporal evolution of the counties in the region after the proposed actions for the regional planning process or any other policy/administrative instrument are implemented. As the first managerial effort, the results established a good baseline in terms of governance for the full region, for each state and for all the littoral counties.

The study area comprises several of the poorest coastal states in Mexico, and the results obtained by means of 
the governance indicators verify the hypothesis that a relationships exist between poverty and low governance level. The significant correlation between poverty and governance level is a very interesting finding and could provide useful information to define governance and/or management interventions at the national, state or county level, starting with actions in the variables that define the most sensitive governance indicators to alleviate poverty. It is proposed as a future line of research further analysis of the relationships and interactions between poverty, governance and environmental quality.

As a managerial and decision-making tool, these indicators and indices may help to promote good practices because they are easy to monitor, transparent, are based on the best available scientific and public information, can be visualized in a GIS and are very useful to integrate not only the regional and marine use planning processes results, but also as a benchmarking strategy for every coastal county or state to attain coastal sustainability.

\section{Appendix}

Supporting Information associated with this article is available online at http://www.aprh.pt/rgci/pdf/rgci-578_AzuzAdeath_Supporting-Information.pdf

\section{Acknowledgements}

Sincerely thanks to the reviewers for their very valuable and useful comments on this paper. This research was funded by SEMARNAT, through the Regional and Marine Planning Process for the Central and Southern Pacific Mexican Coast, technically coordinated by the Institute for Oceanologic Research (IIO-UABC) and the Mexican National Oceanographic Data Center. We appreciate the facilities for the use of information in this paper. Also, we acknowledge the support from the Center for Higher and Technical Education (CETYS-University) through the Engineering School, the graduate program in sustainability and the Engineering Center for Research and Innovation.

\section{References}

Arceo, P.; Granados-Barba, A. (2010) - Evaluating sustainability criteria for a marine protected area in Veracruz, Mexico. Ocean \& Coastal Management, 53(9):535-543. DOI: 10.1016/j.ocecoaman.2010.06.005

Azuz-Adeath, I.; Fermán, J.L.; Espejel, I.; Rivera-Arriaga, E.; Seingier, G. and Vázquez, C. (2010a) - Antecedentes del proceso de construcción de indicadores para la gestión costera y marina ante el cambio climático de la Red Mexicana de Manejo Integrado Costero-Marino. In: E. Rivera-Arriaga; I. AzuzAdeath; L. Alpuche-Gual \& G. J. Villalobos-Zapata (eds.), Cambio Climático en México. Un enfoque costero y marino, pp. 873-900, Universidad Autónoma de Campeche, CETYSUniversidad y Gobierno del Estado de Campeche, D.F., Mexico. ISBN: 978-6077887201. Available on-line at http://etzna.uacam.mx/ epomex/Cambioclimatico.html

Azuz-Adeath, I.; Arredondo-García, M.C.; Espejel, I.; RiveraArriaga, E.; Seingier, G.; Fermán, J.L. (2010 b) - Propuesta de indicadores de la Red Mexicana de Manejo Integrado CosteroMarino. In E. Rivera-Arriaga; I. Azuz-Adeath; L. Alpuche-Gual \& G.J. Villalobos-Zapata (eds.), Cambio Climático en México. Un enfoque costero y marino, pp. 901-939, Universidad
Autónoma de Campeche, CETYS-Universidad y Gobierno del Estado de Campeche, D.F., Mexico. ISBN: 978-607-7887-20-1. Available on-line at http://etzna.uacam.mx/epomex/ Cambioclimatico.html

Baan, P.J.A.; van Buuren, J.T.; Carstensen, J.; Ærtebjer, G.; Manscher, O.H.; Joanny, M.; Rygg, B.; Zenetos, A.; Simboura, N. (2003) - Testing of indicators for the marine and coastal environment in Europe Part 3: Present state and development of indicators for eutrophication, hazardous substances, oil and ecological quality, 65p., European Environment Agency (EEA), Technical Report 86, Copenhagen, Denmark. ISBN: 92-9167508-3. Available on-line at http://www.eea.europa.eu/publicat ions/technical_report_2003_86

Belfiore, S.; Balgos, M.; McLean, B.; Galofre, J.M; Blaydes, M.; Tesch, D. (2003) - A Reference Guide on the Use of Indicators for Integrated Coastal Management. 127p., ICAM Dossier No. 1, Manuals and Guides No. 45, Intergovernmental Oceanographic Commission (IOC-UNESCO), Paris, France. Available on-line at http://www.ioc-unesco.org/index.php?option= com_oe\&task=viewDocumentRecord\&docID $=1799$

Belfiore, S.; Barbiére, J; Bowen, R.; Cicin-Sain, B.; Ehler, C.; Mageau, C.; McDougall, D.; Siron, R. (2006) - A handbook for measuring the progress and outcomes of integrated coastal and ocean management. 217 p. Intergovernmental Oceanographic Commission (IOC-UNESCO), Manuals and Guides, 46, ICAM Dossier No. 2, Paris, France. Available on-line at http://www.iocunesco.org/index.php?option $=$ com_oe\&task $=$ vie wDocumentRecord \&docID $=1800$

Bossel, H. (1999) - Indicators for sustainable development: theory, method, applications. A report to the Balaton Group. 123p., International Institute for Sustainable Development (IISD), Winnipeg, Manitoba, Canada. ISBN: 1895536138. Available on-line at https://www.iisd.org/pdf/balatonreport.pdf

Burbridge, P.R. (1997) - A generic framework for measuring success in integrated coastal management. Ocean \& Coastal Management, 37(2):175-189. DOI: 10.1016/S0964-5691(97)00051-3

Cabral, R.; Cruz-Trinidad, A.; Geronimo, R.; Napitupulu, L.; Lokani, P.; Boso, D.; Casal, C.M.; Fatal, N.A.; Aliño, P. (2013) Crisis sentinel indicators: Averting a potential meltdown in the Coral Triangle. Marine Policy, 39:241-247. DOI: 10.1016/ j.marpol.2012.10.012

Cash, D.W.; Adger, W.N.; Berkes, F.; Garden, P.; Lebel, L.; Olsson, P.; Pritchard, L.; Young, O. (2006) - Scale and Cross-Scale Dynamics: Governance and Information in a Multilevel World. Ecology and Society (ISSN: 1708-3087), 11(2): art.8, Resilience Alliance, Acadia University, Wolfville, Nova Scotia, Canada. Available on-line at http://www.ecologyandsociety.org/vol11/ iss2/art8/

CBD (2004) - Integrated Marine and Coastal Area Management (IMCAM) Approaches for Implementing the Convention on Biological Diversity. 52p., CBD Technical Series No. 14, Secretariat of the Convention on Biological Diversity (CBD), Montreal, Quebec, Canada. ISBN: 9280724096. Available on-line at https://www.cbd.int/doc/publications/cbd-ts-14.pdf

Charron, N. (2010) - Assessing the quality of the quality of governmental data: A sensitivity test of the world bank government indicators. 37p., The Quality of Government Institute, Department of Political Science, The University of Gothenburg, Gothenburg, Sweden. Available on-line at http://www.qog.pol.gu.se/digital Assets/1357/1357980_paper-on-sensititivty-tests-of-world-bank data.pdf

Charron, N.; Lapuente, V.; Rothstein, B.; Varraish, A.; Hernandez, M.; Veisari, L.K.; Dinescu, M.; Popovski, D.; Hakanssson, J.; Jonsson, S.; Morgado, T.; Borgan, O. (2010) - Measuring the quality of government and subnational variation. Report for the European Commission Directorate-General Regional Policy Directorate Policy Development. 161p., Quality of Government Institute, Department of Political Science, The University of 
Gothenburg, Gothenburg, Sweden. Available on-line at $\mathrm{http} / / /$ ec.europa.eu/regional_policy/sources/docgener/studies/pdf/2010_g overnment_1.pdf

Cicin-Sain, B.; Knecht, R.W. (1998) - Integrated coastal and ocean management. 517p. Island Press, Washingtong, D.C. and Covelo, CA, USA. ISBN: 1559636041.

CIMARES (2012) - Política Nacional de Mares y Costas de México. Gestión integral de las regiones más dinámicas del territorio nacional. 97p., Comisión Intersecretarial para el Manejo Sustentable de Mares y Costas (CIMARES), D.F., México. Available on-line at http://www.semarnat.gob.mx/archivosanteriores/ temas/ordenamientoecologico/cimares/Documents/pnmc\%20espa $\%$ C3\% B1ol final.pdf

CONABIO (2009) - Manglares de México: Extensión y distribución. 99 p. Comisión Nacional para el Conocimiento y Uso de la Biodiversidad (CONABIO), Tlaplan, D.F., México. ISBN 978-6077607106 Available on-line at http://www.biodiversidad. gob.mx/ecosistemas/manglares2013/manglaresMex_2009.html

CONAPESCA (2013) - Anuario Estadístico de Acuacultura y Pesca 2013. 295p., Comisión Nacional de Pesca y Acuacultura (CONAPESCA), D.F., México. Available on-line at http://www.conapesca.gob.mx/wb/cona/registro_y_estadistica_pesquera ___acuicola

Day, J.C.; Dobbs,K. (2013) - Effective governance of a large and complex cross-jurisdictional marine protected area: Australia's Great Barrier Reef. Marine Policy, 41:14-27. DOI: 10.1016/j.marpol.2012.12.020

Díaz-de-León, A.J.; Díaz-Mondragón,S. (2013) - Marine Spatial Planning and Large Marine Ecosystems in Mexico. In: K. Sherman \& S. Adams (eds.) Stress, Sustainability, and Development of Large Marine Ecosystems During Climate Change: Policy and Implementation, pp. 95-105, United Nations Development Program (UNDP), Global Environmental Facility (GEF), New York, NY, USA. Available on-line at http://www.undp.org/content/dam/undp/library/Environment $\% 20$ and $\% 2$ 0Energy/Water\%20and\%20Ocean\%20Governance/JFK-AAAS-LMEBOOK.pdf

Duda, A.M.; Sherman, K. (2002) - A new imperative for improving management of large marine ecosystems. Ocean \& Coastal Management, 45(11-12):797-833. DOI: 10. 1016/S09645691(02)00107-2

Ehler, C.N. (2003) - Indicators to measure governance performance in integrated coastal management. Ocean \& Coastal Management, 46(3-4):335-345. DOI: 10.1016/S0964-5691(03)00020-6.

Ernoul, L. (2010) - Combining process and output indicators to evaluate participation and sustainability in integrated coastal zone management projects. Ocean \& Coastal Management, 53(11):711-715. DOI: 10.1016/j.ocecoaman. 2010.10.001

Estrada, S.V.; Viramontes, R.R.; BarreraA.L.G. (2011) - Índice de Marginación por Entidad Federativa y Municipio 2010. Consejo Nacional de Población de México (CONAPO), D.F., México. Available on-line at http://www.conapo.gob.mx/es/CONAPO/ Indices_de_Marginacion_Publicaciones

EU (1999) - European Code of Conduct for Coastal Zones. 98p., Geneve, Switzerland. Available on-line at http://www.coastal guide.org/code/cc.pdf

Fontalvo-Herazo, M.L.; Glaser, M.; Lobato-Ribeiro, A. (2007) - A method for the participatory design of an indicator system as a tool for local coastal management. Ocean \& Coastal Management, 50(10):779-795. DOI: 10.1016/j. ocecoaman.2007.03.005

Garces, L.R.; Pido, M.D.; Tupper, M.H.; Silvester, G.T. (2013) Evaluating the management effectiveness of three marine protected areas in Calamianes Islands, Plawan Province, Philipines: Process, selected results and their implications for planning and management. Ocean \& Coastal Management, 81(SI):49-57. DOI: 10.1016/j.ocecoaman.2012.07.014.
Garcia, S. (1996) - Indicators for Sustainable Development of Fisheries. In: Land Quality Indicators and Their Use in Sustainable Agriculture and Rural Development, pp.131-162, Food and Agriculture Organization of the United Nations (FAO), Rome, Italy. Available on-line at http://www.fao.org/docrep/w4745e/ w4745e0f.htm and https://www.mpl.ird.fr/crea/taller-colombia/ FAO/AGLL/pdfdocs/landqual.pdf

GESAMP (1995) - Biological Indicators and their use in the Measurement of the Condition of the Marine Environment. 56p., Joint Group of Experts on the Scientific Aspects of Marine Environmental Protection (GESAMP), GESAMP Reports and Studies No. 55, UNEP, London, U.K. Available on-line at http://www.gesamp.org/publications/publicationdisplaypages/rs55

GESAMP (1996) - The Contributions of Science to Integrated Coastal Management. 71p., Joint Group of Experts on the Scientific Aspects of Marine Environmental Protection (GESAMP), GESAMP Reports and Studies No. 61, UNEP, London, U.K. Available on-line at http://www.gesamp.org/publications/publicationdisplaypages/rs61

Halpern, B.S.; Longo, C.; Hardy, D.; McLeod, K.L.; Samhouri, J.F.; Katona, S.K.; Kleisner, K.; Lester, S.E.; O’Leary, J.; Ranelletti, M.; Rosenberg, A.A.; Scarborough, C.; Selig, R.E.; Best, B.D.; Brumbaugh, D.R.; Chapin, F.S.; Crowder, L.B.; Daly, K.L.; Doney, S.C.; Elfes, C.; Fogarty, M.J.; Gaines, S.D.; Jacobsen,K.I.; Karrer, L.B.; Leslie, H.M.; Neeley, E.; Pauly, D.; Polasky, S.; Ris, B.; St Martin, K.; Stone, G.S.; Sumaila, U.R.; Zeller, D. (2012) - An index to assess the health and benefits on the global ocean. Nature, 488(7413):615-622. DOI: 10.1038/nature11397

Halpern, B.S.; Walbridge, S.; K. A. Selkoe, C. V. Kappel, F. Micheli, C. D’Agrosa, J. F. Bruno,K. S. Casey, C. Ebert, H. E. Fox, R. Fujita,D. Heinemann,H. S. Lenihan,E. M. P. Madin, M. T. Perry,E. R. Selig, M. Spalding, R. Steneck, R. Watson (2008) A Global Map of Human Impact on Marine Ecosystems. Science, 319(5865):948-951. DOI: 10.1126/science. 1149345.

Hoefnagel, E.; de Vos, B.; Buisman, E. (2013) - Marine informational governance, a conceptual framework. Marine Policy, 42:150-156. DOI: 10.1016/j.marpol.2013. 02.006

House, C.; Phillips, M.R. (2012) - Integrating the science education nexus into coastal governance: A Mediterranean and Black Sea case study. Marine Policy, 36:495-501. DOI: 10.1016/j.marpol.2011.07.007

Kay, R.; Alder, J. (2005) - Coastal planning and management. $2^{\text {nd }}$ ed., 380p., Spon Text, Taylor \& Francis, London, UK / New York, NY, USA. ISBN: 978-0-415-31773-3.

Koleff, P.; Soberón, J. (2008) - Patrones de diversidad espacial en grupos selectos de especies, In: Capital Natural de México, vol. 1: Conocimiento actual de la biodiversidad, pp.323-364, CONABIO, Tlalpan, D.F., México. Available on-line at http://www.biodiversidad.gob.mx/pais/conocimientoActual.html

Mahon, R.; Fanning, L.; McConney, P. (2009) - A governance perspective on the large marine ecosystem approach. Marine Policy, 33:317-321. DOI: 10.1016/j.marpol. 2008.07.013

Malone, T.C.; DiGiacomo, P.M.; Goncalves, E.; Knap,A.H.; TalauMcManus, L.; de Mora, S. (2014) - A global ocean observing system framework for sustainable development. Marine Policy, 43: 262-272. 10.1016/j.marpol.2013.06.008

March, I.J.; Cabral, H.; Echeverría, Y.; Ursúa, F.; García-Rivas, M.C.; Ortíz, O.; Bellot, M.; Frausto, J.M. (2011) - Programa de adaptación al cambio climático en áreas naturales protegidas del Complejo del Caribe de México. 32p., Comisión Nacional de Áreas Naturales Protegidas (CONANP), Fondo Mexicano para la Conservación de la Naturaleza y The Nature Conservancy, Tlalpan, D.F., México. Available on-line at http:// cambioclimatico.conanp.gob.mx/documentos/re_caribe_de_mexico.pdf 
Marques, A.S.; Ramos, T.B.; Caeiro, S.; Costa, M.H. (2013) Adaptive-participative sustainability indicators in marine protected areas: Design and communication, Ocean \& Coastal Management, 10.1016/j.ocecoaman.2011.07.007

Morse, S. (2006) - Is Corruption Bad for Environmental Sustainability? A Cross-National Analysis. Ecology and Society (ISSN: 1708-3087), 11(1):art.22, Resilience Alliance, Acadia University, Wolfville, Nova Scotia, Canada. Available on-line at http://www.ecologyandsociety.org/vol11/iss1/art22/

Nardo, M.; Saisana, M.; Saltelli, A.; Tarantola, S.; Hoffman, A.; Giovannini, E. (2005) - Handbook on Constructing Composite Indicators: Methodology and User Guide. 108p., OECD Statistics Working Papers, 2005/03, Organization for Economic CoOperation and Development (OECD) Publishing, Paris, France. Available on-line at http://www.oecd-ilibrary.org/content/work ingpaper $/ 533411815016$

OECD (1993) - Coastal Zone Management: Integrated Policies. 204p., Organization for Economic Co-Operation and Development (OECD), Paris, France. ISBN: 9264438262.

OECD (1993) - OECD Core set of indicators for environmental performance reviews. A synthesis report by the Group on the State of the Environment, Organization for Economic CoOperation and Development (OECD/OCDE). 39p., Environment Monograph No. 83, OCDE/GD(93)179, Paris, France.

OECD (2008) - Handbook on Constructing Composite Indicators. Methodology and user guide. 158 p. Organization for Economic Co-Operation and Development (OECD) Publishing, Paris, France. Available on-line at http://www.oecd.org social/soc/handbookonconstructingcompositeindicatorsmethodologyand userguide.htm

Olsen, S.; Tobey, J.; Kerr, M. (1997) - A common framework for learning from ICM experience. Ocean \& Coastal Management, 37(2):155-174. DOI: 10.1016/S0964-5691(97) 90105-8

Olsen, S.B. (2003) - Frameworks and indicators for assessing progress in integrated coastal management initiatives. Ocean \& Coastal Management, 46(3-4):347-361. DOI: 10.1016/S09645691(03)00012-7

Pacheco, J.M. (1995) - Indicators of Coastal Zone Environmental Quality: An Annotated Bibliography. 76p., Shorelands and Water Resources Program, Washington Department of Ecology and National Oceanic and Atmospheric Administration (NOAA), Washington, D.C., USA. ISBN-13: 978-1289009519.

Padt, F.; Arts, B. (2014) - Concepts of scale. In: F. Padt; P. Opdam; N. Polman; C. Termeer (eds). Scale-Sensitive Governance of the Environment, pp. 25-41, John Wiley \& Sons, Chichester, UK. ISBN: 978-1118567159.

Pomeroy, R.S.; Watson, L.M.; Parks, J.E.; Cid, G.A. (2005) - How is your MPA doing? A methodology for evaluating the management effectiveness of marine protected areas. Ocean \& Coastal Management, 48(7-8):485-502. DOI: 10.1016/j.ocecoaman.2005.05.004

Poncela, L.; Fermán, J.L.; Espejel, I.; Vázquez, C.I.; Seingier, G.; Azuz, I.; Arámburo, G. (2012) - Environmental quality and equity in the Human Development Index: an integrated index for the Local Agenda 21 case study. Journal of Economics and Sustainable Development (ISSN: 2222-2855), 3(12):39-51, International Knowledge Sharing Platform (IISTE). Available on-line at http://www.iiste.org/Journals/index.php/JEDS/article/view/3 469

Post, J.C.; Lundin, C.G. (1996) - Guidelines for Integrated Coastal Zone Management. 16 p. Environmentally Sustainable Development Studies and Monographs Series No. 9, The World Bank, Washington, D.C., USA. ISBN: 0821337351. Available on-line at $\mathrm{http}: / /$ www.reefresilience.org/pdf/Post_Lundin_1996.pdf
Rothstein, B.; Teorell, J. (2008) - What Is Quality of Government? A Theory of Impartial Government Institutions. Governance, 21(2):165-190. DOI: 10.1111/j.1468-0491.20 08.00391.x

Sardá, R.; Avila, C.; Mora, J. (2005) - A methodological approach to be used in integrated coastal zone management processes: the case of the Catalan Coast (Catalonia, Spain). Estuarine, Coastal and Shelf Science, 62(3):427-439. DOI: 10.1016/j.ecss.2004.09.028

Schernewski, G.; Schonwald, S.; Katarzyte, M. (2014) - Application and evaluation of an indicator set to measure and promote sustainable development in coastal areas. Ocean \& Coastal Management, $\quad$ 101(A):2-13. $\quad$ DOI: $\quad 10.1016 / \mathrm{J} . \mathrm{O}$ CECOAMAN.2014.03.028

Schraad-Tischler, D. (2014) - Sustainable Governance Indicators 2014 and Policy Coherence for Development. 10p., SGI Bertelsmann Stiftung, Germany. Available on-line at www.sginetwork.org

Seingier, G.; Espejel, I.; Fermán-Almada, J.L.; Delgado, O.; Montaño-Moctezuma, G.; Azuz-Adeath, I.; Arámburo-Viscarra, G. (2011) - Designing an integrated coastal orientation index: A cross-comparison of Mexican municipalities. Ecological Indicators, 11(2):633-642. DOI: 10.1016/j.ecoli nd.2010.08.009

Seingier, G.; Espejel, I.; Fermán-Almada, J.L.; MontañoMoctezuma, G.; Azuz-Adeath, I.; Arámburo-Viscarra, G. (2010) - Mexico's coasts: Half-way to sustainability. Ocean \& Coastal Management, 54(2):123-128. DOI: 10.1016/j.ocecoaman.2010.10.034

SEMARNAT (2006a) - Política Ambiental Nacional para el Desarrollo Sustentable de Océanos y Costas de México. Estrategias para su conservación y uso sustentable. 83p., Secretaría de Medio Ambiente y Recursos Naturales (SEMARNAT), Tlalpan, D.F., México.

SEMARNAT (2006b) - Estrategia Nacional para el Ordenamiento Ecológico del Territorio en Mares y Costas. 28p., Secretaría de Medio Ambiente y Recursos Naturales (SEMARNAT), Tlalpan, D.F., México. Available on-line at http://www.inecc.gob.mx/ descargas/ord_ecol/est_nal_oe_mares_costas.pdf

SEMARNAT (2014a) - El Ambiente en Números. Selección de estadísticas ambientales para consulta rápida. $4 .^{\mathrm{a}}$ ed., $59 \mathrm{p}$., Secretaría de Medio Ambiente y Recursos Naturales (SEMARNAT), Tlalpan, D.F., México. Available on-line at: http://www.semarnat.gob.mx/sites/default/files/documentos/estadisticas/ numeralia 2014.pdf

Sherman, K. (2013) - Adaptive management institutions at the regional level: The case of Large Marine Ecosystems. Ocean \& Coastal Management, 90:38-49. DOI: 10.1016/ j.ocecoaman.2013.06.008

Silva, S.; Senaratna Sellamuttu, S.; Kodituwakku, D.C.; Atapattu, S. S. (2011) - Governance Performance in Integrated Coastal Management Sri Lanka: Country Report. 91p., International Union for Conservation of Natura (IUCN), Colombo, Sri Lanka. ISBN: 978-9550205080 Available on-line at http://cmsdata.iucn.org/downloads/integreated_coastal_mgmt.pdf

Smeets, E.; Weterings, R. (1999) - Environmental indicators: Typology and overview. 19p., European Environment Agency (EEA), Technical Report No. 25, Copenhagen, Denmark. Available on-line at http://www.eea.europa.eu/publications/TEC25

Souto, R.D. (2015) - Reanalysis of marine-coastal indicators assessed by national and multinational organizations for the integrated coastal zone management. Journal of Integrated Coastal Zone Management / Revista de Gestão Costeira Integrada, (in press; published on-line 9 DEC 2014). DOI: 10.5894/rgci535

Sutherland, M.; Nichols, S. (2006) - Issues in the Governance of Marine Spaces. In: Administering Marine Spaces: International Issues, 178 p. International Federation of Surveyors (FIG), Co- 
penhagen, Denmark. ISBN 8790907558 Available on-line at http://www.fig.net/resources/publications/figpub/pub36/figpub36.asp

Termeer, C.; Dewulf, A. (2014) - Scale-sensitivity as a governance capability: Observing, acting and enabling. In: F. Padt; P. Opdam; N. Polman; C. Termeer (eds). Scale-Sensitive Governance of the Environment, pp.66-80, John Wiley \& Sons, Ltd., Chichester, West Sussex, UK. ISBN: 978-1118567159.

UN (1992) - Agenda 21 [United Nations Conference on Environment \& Development Rio de Janerio, Brazil, 3 to 14 June 1992]. 350 p. United Nations (UN), Rio de Janeiro, Brazil. Available online

https://sustainabledevelopment.un.org/content/documents/Agenda21.pdf

UN (2012) - Report of the United Nations Conference on Sustainable Development. 120p., United Nations (UN), Rio de Janeiro, Brazil. Available on-line at http://www.uncsd2012.org/ thefuturewewant.html

Van Tatenhove, J.P.M. (2013) - How to turn the tide: Developing legitimate marine governance arrangements at the level of the regional seas. Ocean \& Coastal Management, 71:295-304. DOI: j.ocecoaman.2012.11.004

Vandermeulen, H. (1998) - The development of marine indicatorsfor coastal zone management. Ocean \& Coastal Management, 39(1-2):63-71. DOI: 10.1016/S0964-5691(98) 00014-3

Welsch, H. (2004) - Corruption, growth and the environment: a cross-country analysis. Environment and Development Economics, 9(5):663-693. DOI: 10.1017/S135577 0X04001500

Ye, G.; Chou, L.M; Yang, L.; Yang, S.; Du, J. (2014) - Evaluating the performance of integrated coastal management in Quanzhou, Fujian, China. Ocean \& Coastal Management, 96:112-122. DOI: 10.1016/j.ocecoaman.2014.05.010

\section{Pieces of Legislation}

1988 - Ley General del Equilibrio Ecológico y la Protección al Ambiente. Diario Oficial de la Federación de 28 de enero de 1988. Available on-line at http://ordenjuridicodemo.segob.gob.mx/ Federal/Combo/L-158.pdf

\section{Internet Resources}

INEGI (2010) - México en cifras. Información nacional, por entidad federativa y municipios. ("Total Population" by state), Instituto Nacional de Estadística y Geografía de México (INEGI). http://www.inegi.org.mx/

INEGI-CONABIO-INE (2008) - Ecoregiones terrestres de México, 2008. In: CONABIO web page. Instituto Nacional de Estadística y Geografía (INEGI), Comisión Nacional para el Conocimiento y Uso de la Biodiversidad (CONABIO), Instituto Nacional de Ecología (INE), Tlalpan, D.F., Mexico. http://www.conabio.gob.mx/informacion/gis/layouts/ecort08gw.png

SEGOB (w/d) - Mapa de Sismicidad. Secretaría de Gobernación (SEGOB), Sistema Nacional de Protección Civil de México, D.F., México. http://sismos.gob.mx/en/sismos/

SEMARNAT (2012) - Ordenamiento Ecologíco. Secretaría de Medio Ambiente y Recursos Naturales (SEMARNAT), D.F., México. http://www.semarnat.gob.mx/temas/ordenamiento-ecologico

SEMARNAT (2014b) - Resultados de Calidad del Agua de Mar. Secretaría de Medio Ambiente y Recursos Naturales (SEMARNAT), D.F., México. http://www.semarnat.gob.mx/temas/estadisticas-ambientales/programade-playas-limpias/resultados-de-calidad-de-agua-de-mar

SMN (w/d) -Ciclones que han impactado en México 1970-2011. Servicio Meteorológico Nacional de México (SMN), Comisión Nacional del Agua (CONAGUA), D.F., México. http://smn.cna.gob.mx/index.php?option=com_content\&view=article\&i $\mathrm{d}=38 \&$ Itemid $=102$

SNIA-SEMARNAT (w/d) - Sistema Nacional de Indicadores Ambientales. Indicadores Básicos del Desempeño Ambiental de México. Secretaría de Medio Ambiente y Recursos Naturales (SEMARNAT), D.F., México. http://app1.semarnat.gob.mx/dgeia/indicadores13/conjuntob/00_conjunt o/temas.html 